\title{
Delegation of Governmental Authority in Historical Perspective: Lordships, State Capacity and Development
}

\author{
Daniel Oto-Peralías \\ Universidad Pablo de Olavide
}

August 2019

DRAFT - Comments welcome!

\begin{abstract}
This paper investigates the long-term consequences of delegation of governmental authority through the study of a pivotal local political institution in historical Europe: the lordship. I collect data on seigneurial jurisdictions for ancien-regime Spain and document a negative relationship between having been a seigneurial town in the $18^{\text {th }}$ century and current economic development. To shed light on the causal effect, I focus on the distribution of lordships in the former Kingdom of Granada after its conquest by the Catholic Monarchs, which can be considered as conditionally random. The results confirm the negative effect of lordship found for the whole country: towns that shortly after the conquest were granted to nobles are relatively poorer today. In addition, I explore the mechanisms of persistence, with the results pointing to lower state capacity as a main explanatory factor. This finding is consistent with an interpretation of seigneurial jurisdictions as a privatization of the local government, which has historically hindered the application of central government policies and lowered the state's infrastructural capacity in former manorial towns.
\end{abstract}

Keywords: Lordships, Local political institutions, State capacity, Economic development.

JEL Classification: C21, N43, O10.

Daniel Oto-Peralías. Departamento de Economía, Métodos Cuantitativos e Historia Económica. Universidad Pablo de Olavide, Seville, Spain. E-mail: dotoper@upo.es.

Acknowledgements: Ivan Dondukov and Nuria Adell Raventos provided excellent research assistance. Financial support by the Carnegie Trust for the Universities of Scotland through grant 70433 and the Spanish Ministry of Science, Innovation and Universities through grant ECO2017-86780-R (AEI/FEDER, UE) is gratefully acknowledged. 


\section{Introduction}

This paper investigates the economic consequences of lordships, a key political institution in historical Europe by which monarchs used to delegate their governmental authority at the local level to private agents and entities (Fourquin, 1976; Dewald, 1996). The French aphorism 'no land without a lord' ('nulle terre sans seigneur') illustrates well the historical importance of the seigneurial regime, which largely determined the daily life of local communities until the end of the Ancien Regime. ${ }^{1}$ Lordship is a clear example of delegation or privatization of public functions, which has been a recurrent phenomenon in history. Focusing on old-regime Spain, I first document a negative relationship between $18^{\text {th }}$-century seigneurial jurisdictions and current economic development at the municipality level for the whole country. To make progress towards causality, I study the distribution of lordships in the former Kingdom of Granada after its conquest by the Catholic Monarchs in 1492. Taking advantage that the initial distribution of seigneurial jurisdictions was conditionally random, I show that the negative effect of lordships can be interpreted as causal. The analysis of the mechanisms behind this effect points to state capacity as a key intervening variable. This is consistent with an interpretation of seigneurial jurisdictions as a privatization of the local government, giving rise to a parallel administrative apparatus that undermined the state's infrastructural power in the municipality.

This article contributes to the study of the political economy of lordships, a pivotal institution in medieval and modern Europe that has not received proper attention despite its importance. ${ }^{2}$ Monarchs throughout Europe used to delegate public powers and functions to lords who were in charge of governing large parts of the territory. Lords exercised extensive public powers within the realm of their manors, including the administration of civil and criminal justice, the control of the town council, and monopolistic rights in certain economic activities such as mills and ovens (Dewald, 1996). The improvement of our understanding about the role of lordships in economic development is not only important from the point of view of European and, more generally, Western history. Similar institutions to lordship -as delegation of governmental authority to private actors- are very common throughout history and across countries. For instance, in medieval India land grants gave rise to landlords who collected rents and labor services and exercised fiscal, judicial and military functions, and in early modern Japan the daimyo lords had considerable governing and fiscal autonomy (Ravina, 1999; Sharma, 2003).

The phenomenon of governing through private agents or entities is also related to the practice of indirect rule as a form of government in the context of European colonialism. Feasibility or simply convenience led Metropolitan powers to favor an indirect form of rule through native chiefs, rather than establishing direct political control (Lange, 2009; Iyer, 2010;

\footnotetext{
${ }^{1}$ This aphorism pointed to the fact that most of the land in medieval Europe was in the lords' hands. It was also a legal principle by which all the land belonged to some lord and, ultimately, to the King. For instance, according to the English medieval law, "there was no land without a lord and [...] the normal landholding was the manor, held directly or indirectly of the Crown" (Shannon 2012: 169).

${ }^{2} \mathrm{My}$ analysis focuses on the attribution of jurisdictional rights to secular lords. Throughout the text the expressions lordship, manor, seigneurial jurisdiction and noble jurisdiction are used interchangeably.
} 
Acemoglu et al. 2014; Oto-Peralías and Romero-Ávila, 2014). In addition, another clear manifestation of delegation of governmental authority was the practice of public office-selling, common in diverse settings such as England, France, China and the Ottoman empire, which has been found to have a negative effect on development in the context of the Spanish empire (Guardado, 2017).

I use Spain as a case study to analyze the economic effects of lordships. Spain is a convenient historical setting for several reasons. First, there are rich data on the institutional and economic features of all municipalities of the country during the Ancien Regime. Second, the territory was well balanced between lordship and royal towns, so a meaningful comparison is feasible. Third, serfdom was weak and did not exist after the Middle Ages, which makes it easier to analyze (isolate) the institutional particularities of lordship as an instance of privatization of the local government. Finally, and importantly for the empirical strategy, the Spanish history provides sources of exogeneous variation. During the Reconquista, the Christian kingdoms imposed their institutions on the new lands conquered from Muslim states (Oto-Peralías and Romero-Ávila, 2016, 2017). Monarchs granted lordships in some places but not in others, with the overall institutional and cultural environment being the same. This allows exploiting variation in institutions at the local level while holding constant a wide array of factors.

Whether the delegation of public powers represented by lordships had positive or negative consequences for economic development is an empirical question. On the one hand, the traditional view associated with seigneurial jurisdictions is negative, since vassals supposedly bore higher taxes and were under the (arbitrary) authority of the lord. On the other, lords had incentives to manage in an efficient way their manors in order to attract vassals, maximize their vassals' income and, consequently, their seigneurial rents. Relatedly, lordships could be seen by vassals not only as an extractive institution but also as an institution providing protection against the intervention of the King.

The first part of the analysis investigates the relationship between seigneurial jurisdiction and economic development for the whole country. I collect data on the jurisdictional status of 8,000+ Spanish municipalities in the Ancien Regime from the Census of Floridablanca of 1787 (INE, 1987-1991). There were four types of jurisdiction depending on whether the jurisdictional authority was the Crown (royal jurisdiction or realengo), nobles, military orders, or the Church. I compare, in a regression framework, municipalities under royal and noble jurisdiction, controlling for a wide array of variables and region fixed effects. The results reveal that municipalities that were lay lordship in the old regime are relatively less developed today than former royal municipalities. Moreover, I conduct an adjacent-municipality analysis to compare each lordship with royal towns located within a distance of 50 kilometers from it. The results are consistent with the standard regression analysis showing a negative effect of having been a noble town.

The negative effect associated with seigneurial jurisdiction is in line with the traditional view on it but there may be endogeneity problems making its causal interpretation tricky. Seigneurial jurisdictions were first created in Spain right after the Reconquest but they evolved. Some places originally under royal jurisdiction became lordships because they were granted to nobles or sold to raise money. Conversely, there were also places that gained the royal status 
after making a payment to buy their 'freedom' (Moxó, 1964; Domínguez Ortiz, 1964). While the initial distribution of lordships can be considered (under some conditions) approximately random, the subsequent evolution is likely to be endogenous to local economic and political factors. To make progress towards causality, the second part of the analysis focuses on the former Nasrid Kingdom of Granada, the last Muslim state incorporated into Castile, which constitutes an ideal setting to analyze the effect of local political institutions. Castile transplanted its political institutions into the conquered territory as it had done in previous stages of the Reconquista. This 'transplantation process' can be considered as a 'treatment assignment' in which the 'treatment' (the type of jurisdiction) was externally imposed upon the existing towns and was unrelated to their characteristics. Another advantage of Granada is that, as the last Muslim territory conquered, it is easier to trace the evolution of its local political institutions, and indeed its lordships have been well studied by historians (Soria Mesa, 1997; Pérez Boyero, 1997).

The initial distribution of lordships in Granada can be taken as conditionally random. The Crown kept under royal jurisdiction the main cities, but there was no systematic criterion for the distribution of lordships in the rest of the territory. The Crown had little knowledge, right after the conquest, about the economic potential of each place, and it was precisely within a short period after the conquest when most of the lordships were created. Consistent with this view on the distribution of lordships in Granada, a balancedness analysis shows that lordships are not systematically different than royal places with the exception of distance to capital cities. I find that places initially granted as lordships are today less developed in terms of average income, light emission at night and education, and have experienced less population growth in the $20^{\text {th }}$ century. The results are robust to a large battery of robustness checks. In particular, to address the concern that distance to the capital city may be driving the results, I add a cubic polynomial in distance to the capital, restrict the sample to municipalities with a very similar distribution in this variable, and include very granular distance fixed effects. The negative effect of lordship also holds in an adjacent-municipality analysis.

The last part of the paper analyzes the mechanisms of persistence. I consider several potential channels such as the extractive character of lordships, land inequality, state capacity, and the Church. The results point to state capacity as a main intervening factor. There was less presence of central state infrastructure in lordships by the end of the $18^{\text {th }}$ century -as reflected by a lower percentage of royal employees. This correlates, in turn, with a much lower probability of having a post office in the $19^{\text {th }}$ century, which was an important public service provided by the central government, and with lower provision of public goods today. My interpretation of the results is that lordship, by weakening the link with the central government, historically reduced the state's infrastructural capacity in the municipality, which became a persistent institutional feature. In addition, the data show that lordship towns were not poorer than royal ones in the $18^{\text {th }}$ century, which suggests an evolving role of state capacity over time. In pre-industrial economies, the state was often seen as an extractor of resources and its absence was not necessarily negative for the population's living conditions. However, in industrial and post-industrial societies, the state plays a central role promoting economic development through the provision of a wide array of public goods, and municipalities with less state presence are at a disadvantage. 
Finally, besides shedding new light on the subject of delegation of governmental authority in general and lordships in particular, this paper contributes to the literature on state capacity and development (Gennaioli and Rainer, 2007; Michalopoulos and Papaioannou, 2013; Acemoglu et al., 2015, 2016; Dell et al., 2017). The analysis of the mechanisms of persistence reveals that lordship undermined the state's infrastructural power in the municipality, which is an institutional trait that persists over time. Moreover, this study relates to the literature on the causes and consequences of serfdom to the extent that lordships were the institutional framework enforcing feudal duties -although, as mentioned in Section 2, the seigneurial regime does not require the existence of serfdom (Acemoglu and Wolitzky, 2011; Ogilvie and Carus, 2014; Ashraf et al., 2017; Klein and Ogilvie, 2017; Markevich and Zhuravskaya, 2018). More generally, this article contributes to the vibrant literature on the role played by political institutions in development, "the central issue of economic history and of economic development" (North, 1991: 98), adding new evidence based on within country variation in institutions (Dell, 2010; Bruhn and Gallego, 2012; Michalopoulos and Papaioannou, 2013; Angelucci et al., 2017).

The rest of the paper is organized as follows. Section 2 provides a brief historical background about the origin and evolution of lordships in Spain. Section 3 discusses the data used in the analysis while Section 4 reports the empirical results for the whole country. Section 5 focuses on the distribution of jurisdictional rights in the former Kingdom of Granada to shed light on the causal effect. Section 6 analyzes the mechanisms of persistence. Finally, Section 6 concludes.

\section{Historical background ${ }^{3}$}

\subsection{Lordship in Europe}

Lordship was a pivotal political institution that marked the history of European local communities for a very long stretch of time covering the Middle Ages and the Modern Era. Its remote origins are in the great domain and the villa in Carolingian times and survived until the end of the Ancien Regime (Fourquin, 1976). There were several types of lordships. They could include property rights over land, with the lord being a powerful landowner and the vassals his tenants, or they could just stand for the exercise of public functions (justice and government) over a territory. Although lordships did not challenge the monarch authority, they functioned like a state apparatus at the local level. Fourquin (1976), describing the great fiefs in $14^{\text {th }}$-century France, writes "organized as veritable States, they possessed all the administrative machinery and all the great corps of officers who, in the nature of things, vied with those of the Crown" (p. 231). Besides the village, lordships "formed one of the fundamental local units out of which European society was constituted" (Dewald, 1996: 67). Thus, the manorial regime had a great influence on the daily life of local communities and lords were powerful figures: "Together with his wealth, his power to intervene in tenants' affairs assured the lord a dominant place in local life, and made his household a center of local politics" (Dewald, 1996: 67).

\footnotetext{
${ }^{3}$ A much more detailed historical background is provided in Supplementary Material I.
} 
Although lordships were widespread across Europe, its strength was different from place to place. In the $15^{\text {th }}$ century, northern France and western Germany, where feudal institutions originated, had the strongest manifestation of the seigneurial regime. In regions like Italy and southern France, much land was not under the manorial system because Roman models of property survived. In most of Spain and Eastern Europe lordships were also relatively weak as the need to attract settlers during the Middle Ages led to more freedoms and there was no serfdom or labor services (Dewald, 1996). This picture, however, changed over time. In Center and Eastern Europe lordships became stronger. Lords got new rights and increased their previous ones: labor services, prohibition of leaving the estate, full control of justice and local administration. This strengthening of seigneurial powers mainly reflected the weakness of monarchs and central governments unable to compete with the nobility. "By 1700, lordships in eastern Germany, Poland, Denmark, and Bohemia had grown enormously powerful [...] Spain too witnessed the expansion of seigneurial power during early modern period. Deeply in debt, $16^{\text {th }}$ and $17^{\text {th }}$-century kings used grants of seigneurial rights as means of raising money and rewarding great nobles [...] The crown's weakness gave to lords monopolies, extensive regulatory powers, and the right to levy rents and taxes over peasant subjects" (Dewald, 1996: $69-70){ }^{4}$

\subsection{The seigneurial regime in Spain}

This section provides a brief background of the origin and evolution of the seigneurial regime in Spain. First, it is important to define the concept of lordship used in the analysis. According to the Spanish historiography, lordship is the transfer -by the Crown to a private person or entity- of jurisdictional functions (administration of justice and government) over a specific territory and its inhabitants (Soria Mesa, 1997). In other words, lordship stands for "a set of prerogatives of public law which, over the settlers of a territory, the Crown transfers to who exerts them for his own benefit" (Guilarte, 1987: 28, my translation). This transfer of public powers allows the noble to maintain "troops and fortresses, to judge in an instance above the municipality courts, to appoint the holder of many council posts, and to receive rights and rents" (Laredo Quesada, 1989: 149, quoted in Pérez Boyero, 1997: 17, my translation). Lords were also commonly landowners within their manors, so their vassals were also their tenants, but this was not necessarily the case.

Depending on the holder of the seigneurial jurisdiction, there were noble, ecclesiastical

\footnotetext{
${ }^{4}$ It is worth noting that feudalism and lordship refer to different phenomena. A central feature of feudalism is the splitting up of public powers that in ordinary are exercised by the State, implying the fragmentation of sovereignty. Two key elements of feudalism were the existence of personal bonds and the impact of these bonds on the state. Bonds of vassalage made up the political structure of society. (Fourquin, 1976). In contrast, the lordship system did not challenge the power of the state: "Whether or not the great landowners possessed the right of administering justice had nothing to do with the disintegration of the State" (Fourquin, 1976: 12). In this sense, monarchical absolutism did not eradicate the seigneurial system. Rather, it integrated the latter into the monarchical structure, placing the manorial system in a clear subordinate position (González Alonso, 1983). Relatedly, the seigneurial system does not require the existence of serfdom, a feudal institution. Lordship is fully compatible with free peasants.
} 
(including monastic) and military order lordships. Places that were not subject to the seigneurial regime depended directly on the royal administration and therefore had royal jurisdiction (realengo towns). Figure 1 depicts the geographic distribution of the different types of jurisdiction in Spain in 1787. I focus on royal and noble jurisdictions, which were by far the most common types.

Lordships initially had a clear instrumental purpose during the Reconquest and subsequent repopulation of former Muslim lands in Spain. Nader (1990) mentions that the "development of municipalities was the foundation of the seigneurial regime in Castile" (p. 47). The interest of lords in developing settlements and promoting agriculture and population growth matched well with the objective of the Crown of repopulating and defending the conquered territory. Factors such as the southward expansion of the frontier in the Christian kingdoms and the feudal influence from Europe accelerated the creation of lordships in the $12^{\text {th }}$ and $13^{\text {th }}$ centuries. During all this first period, lordships had the goal of promoting the repopulation of the territory and defending the frontier. The link of lordships to land (hence, the rights of lords over land) is stronger in this period due to this colonizing function (Moxó, 1964).

The Trastamara dynasty that started in the mid-14 $4^{\text {th }}$ century constituted the most important source of lordships in Castile. The new monarchs granted lordships as a reward for support during the dynastic war and to compensate the reduction in lords' rents due to negative shocks such as plague and war. Despite this expansion of the seigneurial regime, royal jurisdiction (realengo) remained predominant in the main cities (Cabrera, 2004). Monarchs transferred extensive jurisdictional and property rights to lords. However, as time passes, the new lordships are granted in lands already populated, which implied a reduction in the rights of the new lord, particularly with respect to land ownership. According to the Ordenamiento de Alcala (1348), the rights of preexisting settlers over land had to be respected. ${ }^{5}$

The growth of the manorial system went down during the reign of the Catholic Monarchs as they tried to preserve the existing realengo places and moderate the power of lords. For instance, they approved the Pragmática de Medina del Campo (1480), which established the freedom of movement of vassals (Moxó, 1964). In the same vein, Catholic King Ferdinand freed the Catalonian remença serfs through the arbitral ruling of Guadalupe in 1486.

Spain entered the Modern Era inheriting a very large number of lordships from the Middle Ages. The French aphorism "no land without a lord" was to a considerable extent true in the second half of the $15^{\text {th }}$ century (Valdeón, 1997). After 1500, the financial needs of the Crown are the main driver of the creation of lordships. Two stages can be differentiated. In the first one, the lordships created by Emperor Charles V and his son Phillip II have a similar character to the previous ones. They sold a significant proportion of ecclesiastical and military orders lordships, thereby creating many new lay manors. In the second stage, during the $17^{\text {th }}$ century, there were many sales of royal villages and towns, but buyers just received

\footnotetext{
${ }^{5}$ It is interesting to note that, except for the military orders, the territorial extension of individual lordships was not very large as they were geographically fragmented (that is, the same noble lineage owned several lordships scattered across the territory rather than concentrated on a specific area). This prevented that lords could challenge the sovereign of the King. Rather, lordships played a major role at the local level, becoming "a relevant institution within the sphere of the local administration" (Moxó, 1964: 189, my translation).
} 
jurisdictional rights. Thus, these late sales, when lordships had completely lost their colonizing mission, only consisted of public functions, that is, the jurisdiction in strict sense. The economic value of that (i.e., the rents that could be earned) was very limited. The reasons to buy a jurisdiction had basically to do with social prestige, the desire to enter the nobility (Domínguez Ortiz, 1964). 6

The advent of the Bourbon dynasty put an end to the expansion of the seigneurial regime in Spain. Regarding the situation of the manorial system in this period (i.e., the $18^{\text {th }}$ cent.), it is difficult to generalize. Nevertheless, a few remarks are worth making. First, the economic value of seigneurial exactions was generally low, although some privileges such as the lord's monopolies generated many complaints; second, the hardship of the vassal's situation depended on whether the lord also owned the land; third, there was heterogeneity across the main regions of Spain, and even within regions; and fourth, lords preserved their control of the local justice and capacity to intervene in the local government. Although less pervasive than in the past, this jurisdictional power gave lords legal superiority over their vassals and a guarantee that their rights would prevail. Concerning the lord's control of the town council, his power and capacity to intervene varied from one place to another but was in general very effective and went together with the right to issue ordinances (Domínguez Ortiz, 1955).

The seigneurial regime was abolished by a number of legal reforms that started at the Cortes de Cadiz in 1810. At that time, the manorial regime had lost much of its economic significance in the sense that the seigneurial rents collected were low, although continued to be a relevant local political institution. Where lords were also landowners, which was common, they had lost interest in jurisdictional rights and become rentiers. This change, observed also throughout Europe, in the nature of lordships at the end of the Ancien Regime helps explain the outcome of the measures at the Cortes de Cadiz: jurisdictional rights were eliminated but lords maintained and consolidated their property rights in their old lordships, namely, those coming from the Middle Ages and the first century of the Modern Era (Moxó, 1964).

\subsection{Seigneurial vs royal jurisdiction}

Were royal towns seen as preferable to lordships? In order words, were the living conditions better in royal places than in seigneurial ones? The most intuitive and widespread view is that people were better off under royal jurisdiction, that is, depending directly on the King and thus avoiding the abuses of power and arbitrariness of lords. The historiography on this subject has a more mixed view though, arguing that noble jurisdiction was not necessarily worse than the royal one.

On the one hand, there is evidence suggesting that people preferred to live in royal places. For instance, when the Crown decided to sell the jurisdiction of a royal town, there were often desperate attempts by the population of the affected towns with the purpose of avoiding such a yoke (Soria Mesa, 1997). There were also many instances of anti-seigneurial movement in which the population, often led by the urban oligarchy, tried by violent means to oppose the

\footnotetext{
${ }^{6}$ An economic factor largely responsible for the reduction in value of seigneurial rents was the high inflation of the early modern period (Dewald, 1996).
} 
rule of the lord. ${ }^{7}$ In addition, some references indicate that the control of the territory by the nobility was an obstacle for its repopulation because lords imposed restrictions on activities such as hunting, woodcutting or pasturing, and levied higher taxes (Vassberg, 1984). ${ }^{8}$

On the other hand, there is also some evidence indicating that lordships were not worse than royal towns. For instance, for the case of Granada from 1570 to 1750, there was more immigration to lordships than to royal towns, which suggests that living conditions in lordships were not worse than in royal places. Historical references indicate that lords were able to provide protection to their vassals against taxes levied by the King and against royal commands and repressive institutions such as the Inquisition. Relatedly, lords sometimes offered tax exemptions to attract new vassals. The purpose of lords was not altruistic but the maximization of income as their rents depended on the number of vassals. There are examples of lords trying to promote economic development in their lordships, as this would increase their rents (Soria Mesa, 1997).

The sale of lordships in the $17^{\text {th }}$ century is a good setting to study how the population reacted to a change from royal to noble jurisdiction. In relation to the massive sale of jurisdictions during the reign of Phillip IV, which affected 230,000 inhabitants, Domínguez Ortiz (1964) argues that, overall, the attitude of towns was heterogeneous. There are certainly testimonies of reaction against becoming vassal of a lord, and in general jurisdictional changes of status did not generate enthusiasm, but violent responses were rare. Thus, changes were generally accepted with resignation, "as a lesser evil" (Domínguez Ortiz, 1964: 182). ${ }^{9}$ Whether the change to noble jurisdiction was beneficial or detrimental to the population is an unanswered question. In some cases, the change led to the migration of important families that did not want to be under the authority of a lord, but in towns without such a middle-upper class, the change was not necessarily detrimental. In words of Domínguez Ortiz (1964), "the lord was interested in increasing the value of his new possession; he often offered privileges, attracted settlers, established pious foundations and defended the villagers from the excesses of collectors and executors" (p. 182, my translation). Similarly, Vassberg (1984) states that "many lords established fairs and freemarkets to invigorate the economy of their towns [...] More importantly, the lords, in their own interest, tried to preserve their vassals from the worst

${ }^{7}$ During the low Middle Ages, the most common causes of grievances and complaints by vassals were abusive taxes, usurpation of common lands, acquisition of lands by fraudulent means, usurpation of jurisdictional rights, excessive control of the appointments for local council's posts, abuses in the obligation of providing lodging to the lord's servants, and even abusive intromission in their vassals' marriages (Cabrera, 2004).

${ }^{8}$ Contemporaries did not often have a good opinion of lordships. The geographer Tomás López, during the second half of the $18^{\text {th }}$ century, interviewed priests for his historical survey of the kingdom. It appears that they generally had a negative view of the manorial administration (Domínguez-Ortiz, 1955). For instance, the priest of a town in Cáceres said "the government is exercised by two mayors who are elected each year by the owner of the jurisdiction without participation of the council or any other person; the lord's administrator is the only in charge of these appointments; if he, as usually happens, governs following private interests, the less worthy people are appointed and the government subverts" (Domínguez Ortiz, 1955: 325, my translation). Moreover, frequent perpetual conflicts between some towns and their lords often resulted in very lengthy lawsuits of more than 100 years duration.

${ }^{9}$ This was particularly the case in small towns that were under the control of a city, and this category of towns was the most affected group by the sales in quantitative terms. 
effects of billeting or tax collection" (p. 97-98). The safeguard or benefit for the community was greater when the seigneur was powerful and influential.

Overall, although negative references are more common than positive ones, historians are generally reluctant to state that lordships were worse than realengos. Rather, it is argued that the jurisdictional status is not very informative to explain the living conditions of the population. In this sense, Ruiz (1998) argues that whether they lived in royal or seigneurial jurisdiction "really provides little indication of how much money (rent) individual peasants paid, how much land they held, and under what conditions. In principle, peasants living in royal lands owed less dues than those under seigneurial jurisdiction, but local conditions, more often than not, determined the types of payments and tenure" (p. 52-53). Finally, Vassberg (1984) provides a well-balanced summary of the question. He concludes that the vast majority seemed to prefer royal jurisdiction, ${ }^{10}$ although one would be wrong to infer that royal jurisdiction was always preferable to lordship -particularly, if the lord was benevolent, life under lordship could be easier.

\subsection{Concluding remarks}

The seigneurial regime was heterogeneous across and within countries. For the case of Spain, the rights of lords and the situation of vassals largely depended on the local circumstances of each place, being difficult to generalize. What all lordships did have in common was the transfer of jurisdictional functions to private agents, representing a form of privatization of the local government. In addition, it was a general fact that seigneurial rents (those associated with jurisdictional rights) lost economic significance over time. At the end of the Old Regime, lords' rents from landownership were much more important than seigneurial rents. This was true everywhere in Europe and in Spain itself. Moreover, it seems that the population generally preferred the royal status, but life in lordships was not necessarily worse than in realengo towns.

One may wonder whether the seigneurial regime had an impact on the development path of towns and regions. Even though the historiography maintains that the situation of vassals was not necessary worse than that of royal towns' residents, there is no systematic empirical study of this question. More interestingly, it is possible that vassals were not worse off, but perhaps the institutional legacy of lordships has been detrimental to the subsequent development of seigneurial towns. One possible hypothesis is that the seigneurial administrative apparatus reduced the presence of the state in the municipality and -thus- its capacity to implement policies. The protection provided by the lord against the royal administration (preventing or hindering the intervention of royal officials to collect taxes, host troops, etc.) could be beneficial in the short-term, but could create negative institutional and cultural dynamics.

\section{Data}

I collect data on the jurisdictional status, total population and job occupation structure of all

10 The preference for royal towns "is reflected in several Castilian proverbs [such as] En lugar de señorío no hagas tu nido (Don't build your nest in a seigneurial town)" (Vassberg, 1984: 98). 
the villages, towns and cities of Spain in the $18^{\text {th }}$ century from the Census of Floridablanca (INE, 1987-1991). This population census is a milestone in the history of demographic statistics. No other major western country has a population census with a comparable quality (Pérez Moreda, 2010). Both the original census and the modern publication are monumental works. The former consists of more than 50,000 manuscript pages and the latter of more than 6,000 pages. The census contains, for each one of the more than 20,000 population entities or settlements existing in the country in 1787, data on its political and administrative characteristics, total population, religious communities, and the population classified by age group, civil status, sex, and job occupation. For the construction of the dataset, I have focused on the political and administrative features, total population, and the classification of the population by job occupation.

These census data are used to create a dataset for modern-day municipalities. I use the list of municipalities corresponding to the year 2013 (about 8,100), provided by the National Geographic Office (Instituto Geográfico Nacional, 2013). All the details about the collection of census data and the creation of the dataset at the municipality level can be found in Supplementary Material II: " $18^{\text {th }}$-century Spain: A dataset of political institutions and socioeconomic variables at the local level", available on the author's website. Table 1 summarizes the distribution of municipalities, population and surface area by type of jurisdiction. Noble jurisdiction was the most common jurisdiction among the population entities of the Ancien Regime, which also applied when considering modern-day municipalities. The second most frequent category was royal jurisdiction. These two categories together account for about $80 \%$ of all population entities. A much lower percentage of places were under the jurisdiction of the Church and the military orders. In terms of population, royal jurisdiction was the most important, particularly when considering current population data, while in surface area both noble and royal jurisdictions occupied the same percentage of the territory. All in all, not all the land nor the population was in the hands of lords, but lordships were clearly a very important local political institution until the $19^{\text {th }}$ century.

I also collect data on the initial distribution of lordships in the former Nasrid Kingdom of Granada. As mentioned above, this territory was the last Muslim state incorporated into Castile and it is easier to trace the origin and evolution of the jurisdictional status of each village and town. I collect data on the date and method of acquisition of each lordship from Soria Mesa (1997), which is complemented -if necessary- with other sources including Pérez Boyero (1997), Garzón Pareja (1977), and Segura Graiño (1982). More information about the construction of the dataset of Granadian lordships is provided in Section 5. Finally, I also gather data on a wide array of geographic and climatic variables, preexisting conditions, as well as current outcomes. To save space, the descriptions and sources of all the variables used in the analysis are provided in Table A1, while the descriptive statistics are available in Table A2, both in Supplementary Material III: "Variables' descriptions and robustness checks".

\section{Lordships and economic development in Spanish municipalities}

This section analyzes the relationship between lordships in 1787 and current economic outcomes. I focus on the comparison between royal and noble jurisdiction, by far the two most 
common types. Observations with the other types of jurisdiction are omitted. First, it is useful to take a look at the correlation of lordships with geographic, climatic and pre-existing historical conditions. This helps assess the extent to which the assignation of the seigneurial status to towns was exogenous to their economic potential. Table 2 reports the coefficient on lordship controlling for region fixed effects (i.e., dummy variables capturing Spain's seventeen self-governing regions). There are no differences in altitude, ruggedness, soil quality, temperature, rainfall, aridity, distance to the coast, distance to a major river, distance to Madrid, distance to Roman roads, and distance to pre-medieval settlements. There is only a statistically significant difference in distance to the provincial capital city, being the coefficient positive. The latter is expected since most of the important cities where kept under the direct control of the Crown (i.e., royal jurisdiction). Therefore, this indicates that distance to the capital city is an important control variable.

\subsection{Standard regression analysis}

To study the relationship between noble jurisdiction and economic development, I estimate the following equation using ordinary least squares and clustering standard errors at the region level:

$$
Y_{i, r}=Y \cdot \text { Lordshipi,r }_{i} \beta \cdot X_{i, r}+\eta_{r}+\varepsilon i, r \quad \text { Eq (1) }
$$

where $Y_{i, r}$ represents a current outcome variable for municipality $i$ in region $r$, Lordshipi,r is a dummy variable measuring whether the municipality was under noble jurisdiction in 1787 , $X_{i, r}$ represents a vector of control variables related to the geographic, climatic and pre-existing historical features of the municipality, $\eta_{r}$ is a set of 17 region dummies, and $\varepsilon i, r$ is the error term. Regarding the vector of control variables, I include altitude, ruggedness, temperature, rainfall, a coast dummy, distance to the coast, a capital city dummy, distance to the capital city, and the quadratic polynomial in latitude and longitude. By including a wide array of variables related to the geographic location of municipalities I try to prevent the spatial dimension of the local data from influencing my results.

With respect to the current outcome variables, the closest available indicator at the local level to measure income per capita comes from tax returns and measures the average gross income, calculated as total gross personal income divided by the number of taxpayers in each municipality. This indicator has the shortcoming that is only available for municipalities larger than 1,000 inhabitants, which represents less than $40 \%$ of Spanish municipalities. In terms of population, however, municipalities larger than 1,000 inhabitants account for $90 \%$ of the overall Spanish population. In terms of surface area, they account for almost $60 \%$ of the total. Therefore, this measure of income actually covers most of the territory and almost all the population. I also collect data on other proxies for economic development at the local level with a wider geographic coverage. These include light density at night, average number of vehicles per household, educational attainment, and average socioeconomic condition. I also use annual population growth during the $20^{\text {th }}$ century as a basic measure of the economic success of municipalities.

Column 1 of Table 3 reports a negative and statistically significant relationship between 
noble jurisdiction and income. Municipalities under noble jurisdiction in 1787 have today $4 \%$ less gross average income than municipalities under royal jurisdiction. Columns 2 shows, for the whole sample, that former seigneurial towns have $12 \%$ less light density at night. The rest of columns include average number of vehicles per household, education attainment, average socioeconomic condition and long-term population growth. The variable lordship always carries a negative and statistically significant coefficient, expect in column 5. I have checked that the negative effect associated with noble jurisdiction is robust to using province fixed effects rather than region fixed effects. I have also checked that the results are broadly robust to restricting the sample to municipalities with tax income data (i.e., larger than 1,000 inhabitants in 2013).

One may be concerned about the possibility that distance to the capital city is somehow driving the negative effect of lordship. Although the previous set of regressions controls for distance to the capital city, it is still possible that the relationship of this variable with current outcomes is nonlinear, which would imply that the model is misspecified. I address this concern through two avenues: first, I include a flexible (cubic) polynomial in distance to the capital city and, second, I introduce very granular distance fixed effects consisting of 1-km bins. Reassuringly, the results are largely robust although the coefficient on lordship becomes slightly smaller. ${ }^{11}$

\subsection{Adjacent-municipality analysis}

As an alternative approach, I conduct a local analysis in which each municipality with noble jurisdiction is compared to a group of adjacent municipalities with royal jurisdiction. ${ }^{12}$ The purpose of this exercise is to create, for each municipality with noble jurisdiction, a comparison (control) group of neighbors with royal jurisdiction. In this way, I compare municipalities that are very similar in geographic, climatic and locational characteristics. More specifically, I execute the following algorithm for each municipality with noble jurisdiction: i) find its 10 nearest neighbors with royal jurisdiction, ii) delete neighbors more than $50 \mathrm{~km}$ away of the municipality, iii) take averages, for each variable used in the analysis, for the resulting group of neighbors in step 'ii', and iv) calculate the difference, for every variable, between the municipality and its comparison group of royal neighbors. This renders, for each variable and for each lordship municipality, the difference between the municipality's value and its neighbors' average value.

Table 4 reports the results. Odd columns only include an intercept, which reflects the unconditional mean difference in the dependent variable. The coefficients reveal that lordships are associated with less income, light emission, education, average socioeconomic condition and population growth. The differences are statistically significant with the exception of column 9 . Control variables capturing differences in geographic and climatic factors are added in even columns. The variable of interest is again the intercept, which reflects the average difference between lordships and royal municipalities when differences in the observables are zero. The results are very similar when introducing these controls. Moreover, it is worth noting that the

${ }^{11}$ All these unreported results are available in Supplementary Material III.

12 This analysis is similar in spirit to the one by Michalopoulos (2012), who focuses on pairs of contiguous regions. 
difference between lordship and royal jurisdiction in this analysis of adjacent municipalities is similar to that found in the previous standard regression analysis.

To sum up, the evidence reported in this section indicates that municipalities that had noble jurisdiction in the Ancien Regime are relatively poorer today. This result holds both in a standard regression framework with region fixed effects and in a systematic comparison of adjacent municipalities. However, there may still be some caveats regarding whether this negative relationship can be interpreted as causal. The geographic distribution of lordships in 1787 is partially endogenous. Since the initial distribution of lordships that took place after the Reconquest, there has been a long evolution in the jurisdictional status of settlements, and some unobserved relevant factors could have affected this evolution. ${ }^{13}$ To shed more light on the causal effect of lordships, I focus in the next section on the territory of the former Nasrid Kingdom of Granada, which provides a better setting to tackle this question.

\section{Lordships and economic development: The case of Granada}

\subsection{The seigneurial regime in Granada.}

\subsubsection{Initial distribution of lordships.}

The Nasrid Kingdom of Granada was the last Muslim state conquered by Castile (c. 14821492). As a conquered land, its institutional framework was created from scratch. The Catholic Monarchs transplanted the Castilian institutions into the new territory as their predecessors had done in the past. An advantage of focusing on Granada is that its more recent conquest makes it easier to study and collect data about the initial distribution of lordships and its evolution. For this purpose, there are excellent studies by medieval and modern historians (Soria-Mesa, 1997; Pérez-Boyero, 1997). Importantly for my empirical strategy, most of the Granadian lordships were created right after the conquest. Granada passed into Christian hands in January 1492 and most of the lordships were granted five months later, in June. The Catholic Monarchs granted them in compensation for military help, palace services and financial loans. The main beneficiaries of these grants of seigneurial jurisdictions were members of the nobility who already had lordships in other regions of the country. The Granada Kingdom was thus used as an economic reserve to reward the conquerors and, as Queen Isabella ordered in her will, to pay personal and political debts (Soria Mesa, 1997; Peinado, 2011).

The Crown's policy was initially to repopulate the main cities with Christian settlers from other parts of the kingdom, while maintaining a Mudejar majority in the countryside. ${ }^{14}$ The main cities and the surrounding areas were kept as royal jurisdiction, following the example of

13 The most common change in status was from royal to noble jurisdiction. It is unclear the direction of the potential biases arising from this process. For instance, powerful royal towns could have lobbied to avoid becoming a lordship, introducing a downward bias in my estimates. Acting in the opposite direction, beneficiaries and buyers of jurisdictions could have been interested only in attractive places, creating an upward bias.

${ }^{14}$ Mudejars refer to the Muslim population of al-Andalus that remained in Spain after the Christian conquest. Moriscos refer to Mudejars forcibly converted into Christianity. 
the repopulation of the Guadalquivir Valley, whereas the rest of the territory was partially granted to nobles. Importantly, beyond the main cities, there was no clear criterion for the initial distribution of lordships. ${ }^{15}$ Soria-Mesa (1997) states that "in the distribution [of lordships] it dominated the ignorance of the Granadian geography and the logical confusion produced by foreign toponyms" (p. 57, my translation). Because of this confusion and lack of knowledge, the royal chancery made some mistakes when identifying certain places (Pérez Boyero, 1997). ${ }^{16}$ In addition, it is worth noting that the Catholic Monarchs did not grant any lordship to the Church and military orders, as they did not want to increase their already huge power (Pérez Boyero, 1997). Laredo Quesada (1968) points out that "along with the control by the Crown, the second feature of the repopulation was that of being conducted according to the circumstances of each conquest and each capitulation" (p. 492, my translation). This also introduces an element of randomness since these were contingent factors of that time. In this regard, Almería and Málaga are the provinces where more lordships were granted arguably because they were conquered first and monarchs needed to materialize soon the rewards to nobles for their military help (Birriel Salcedo and Soria Mesa, 1993). Defense needs also had some relevance but its importance was circumscribed to specific areas such as the coast. ${ }^{17}$

The size of the lordships created in Granada was not as large as in some parts of Castile, but they were not small nor unimportant (Soria Mesa, 1997). One of the reasons for the relatively small size of lordships was that the Catholic Monarchs aimed to maintain the balance of power among the noble families, which influenced their policy regarding the distribution of lordships. To maintain that balance, they did not grant very large lordships (Pérez Boyero, 1997). Regarding a potential selection bias, in Soria Mesa (1997)'s view, the Crown did not choose the worst places (or least profitable) to create lordships. For instance, the western part of Almeria is a mountainous area with difficult communications. From this broad area, the only places that were granted as lordships were the least steep ones, with better communication and availability of water: "For this reason is why the manors are given,

15 An exception to this was that some lords with possessions on the former Granadian frontier received places near to their estates (Soria-Mesa, 1997).

${ }^{16}$ An example of the poor knowledge of the Crown about the Granadian territory was the agreement dated in April of 1495 to grant several lordships to the count Luis de Beaumont, constable of Navarre. "As circumstances forced to act quickly, the Monarchs decided to grant to the constable of Navarre the jurisdiction of Huéscar, Castilléjar [...] The decision was made without having enough information about the number of inhabitants and the value of the rents of these towns" (Pérez Boyero, 1997: 36, my translation; italics are mine). This suggests that as late as in 1495, three years after the capitulation of Granada, the Crown did not have systematic information about the basic characteristics of Granadian towns. Furthermore, there was also lack of knowledge from the point of view of the beneficiaries of lordships, suggesting that the monarchs' decisions were not based on specific nobles' demands. For instance, Catholic King Ferdinand II granted Almayater in 1508 to the count of Tendilla to pay his services as ambassador in Rome and with the purpose of repopulating the Granadian coast. Shortly after, the count of Tendilla organized a visit to the place as he "wanted to get his first look at Almayater, "this gift that the king gave me"', getting a very bad impression of the conditions in which he found the place (Nader, 1990: 48).

${ }^{17}$ For instance, Segura Graíño (1982) points out that Adra, in Almeria, was realengo because of its fortification and good location for the defense of the coast. Indeed, in that province, the Crown was concerned about a potential landing of Muslim forces and kept most of the coast under royal jurisdiction. The inclusion of a coast dummy variable in the regressions controls for the bias that may arise from this. 
in the places where there is water in greater abundance" (Segura Graiño, 1982: 610, my translation). The empirical analysis conducted below shows that there are no statistically significant differences in geographic and climatic factors between lordships and royal towns. The only significant difference is that lordships tended to be located further from capital cities.

To sum up, there was no systematic policy for the distribution of lordships, except for the fact that the main cities remained realengo. According to López de Coca (1993), "it is legitimate to ask whether there existed any criterion in the distribution of lordships" (p. 141, my translation). All this discussion suggests that the geographic distribution of lordships was conditionally random. That is, taking into account the fact that the main cities remained royal, for the rest of the territory there was apparently no criterion. This implies that the initial distribution of lordships was (conditionally) exogenous to the economic characteristics and economic potential of the territory.

\subsubsection{Evolution of the seigneurial regime in Granada and lords' prerogatives.}

The distribution of seigneurial jurisdictions in Granada did not remain static. Sales of lordships started in the 1550s driven by the financial needs of the Crown and stimulated by a pre-existent demand (Pérez Boyero, 1997). There was demand for lordships in places in which interested buyers had properties. Thus, seigneurial jurisdictions were generally sold in places with large estates, which suggests that the randomness of the subsequent distribution of lordships was lower than that of the initial distribution. Buyers were generally urban upper classes, owners of large estates in the affected territory, being almost always the city councilors (regidores) -hence arising a clear conflict of interest (Soria Mesa, 1997). The sale of lordships accelerated during the first two decades of the $17^{\text {th }}$ century under the reigns of Phillip III and

Phillip IV. It is worth noting that not all sales of jurisdictions became effective. About half of the times the local community or the city council were successful opposing to become a lordship (Soria Mesa, 1997). This fact can also introduce a bias in the type of towns making up these late lordships.

Finally, regarding the rights and prerogatives of Granadian lords, it is important to differentiate two stages. The first one spans from the time of the conquest until 1568 and is characterized by high rents from the exploitation of the Morisco population. Moriscos paid heavy tributes. After the conquest, Castilian lords maintained (and when possible increased) the previous high tax burden, which included labor services. Despite this highly extractive institutional framework, Moriscos preferred lordships because lords were much more permissible regarding their culture and customs. The second stage started after the Morisco uprising in 1568 and their subsequent expulsion from Granada. Their expulsion had a very negative impact on lords' rents. Not only had they seen a reduction in the number of vassals, but also in the type of vassals. The new ('old Christian') vassals had more rights and paid much less. The whole repopulation process after the expulsion of Moriscos was controlled and organized by the King (Muñoz Buendía, 1992; Soria Mesa, 1997). For this second period, which covers almost all the Modern Era until the $19^{\text {th }}$ century, the main source of income of Granadian lords were the tercias, which amounted to one third of the tithe. Additional sources of income were the alcabalas (a sales tax) and rents from properties that lords had in their 
lordships. Other sources of income with much lower importance were the seigneurial rents related to the administration of justice, local monopolies and appointments of local officials. Regarding the jurisdictional power of lords, it was similar to the rest of Castile as it basically consisted of the administration of justice and the appointments of town councilors (Soria Mesa, 1997).

\subsection{Empirical analysis}

This section analyzes the effect of lordships granted shortly after the conquest on current economic outcomes. I refer to 'old lordships' as those created before 1515, all of them the result of royal grants. Table 5 shows that old lordships are very similar to the rest of municipalities in terms of geographic and climatic conditions as well as in pre-medieval variables. There is a minor and marginally significant difference in temperature: lordship towns are 0.5 degree Celsius colder. Lordship municipalities are closer on average to a major river (the Guadalquivir), which is a positive characteristic favoring the economic development of seigneurial places. The positive and significant coefficient with respect to distance to the capital city is more worrisome as this factor may exert a negative impact on development outcomes. Distance to the capital city is therefore again a very important geographic control in the regressions. The results of Table 5 are consistent with the previous historical discussion: the only criterion for the distribution of lordships was to keep the largest cities under royal jurisdiction. Beyond the main urban centers, the Crown was largely indifferent. Therefore, the initial distribution of lordships in Granada can be considered conditionally random: controlling for distance to the capital city and including capital city dummies, it is possible to identify the effect of lordship on local economic development. The exogeneity of lordship is also favored by the fact that Granada was a conquered land and its institutional and economic orders were fully reset in less than a hundred years. Particularly with the expulsion of Moriscos after the revolt in 1568, the Castilian Granada had very little to do with the former Muslim country (Ladero Quesada, 1979).

I estimate the following equation to analyze the effect of the initial distribution of lordships on long-term economic development:

$$
Y_{i, r}=\Upsilon \cdot \text { Old Lordhips }+\beta \cdot X_{i, r}+\varepsilon i, r \quad \text { Eq (2) }
$$

where all the variables are the same as in Eq (1) except the main independent variable which is a dummy variable capturing whether the municipality was a lordship early in the $16^{\text {th }}$ century. I report Conley (1999)'s standard errors robust to spatial correlation of unknown form. ${ }^{18}$ Table 6 presents the baseline results. The coefficient on the variable of interest is always negative and statistically significant. Its magnitude is larger than in the analysis using the whole Spanish sample. Lordship towns have today $7.5 \%$ less income, $48 \%$ less night light density, 0.46 standard deviation less vehicles per household, $4.1 \%$ less people with secondary and higher education, and 0.33 standard deviation less socioeconomic condition. They also had $0.52 \%$ lower annual population growth in the $20^{\text {th }}$ century.

This negative effect is not driven by distance to the capital city as this variable is included

${ }^{18}$ I employ cutoffs of 1 decimal degree, beyond which spatial correlation is assumed to be zero. 
in the control set. In addition, the quadratic polynomial in latitude and longitude controls, in a more general way, for the potential confounding effect that the municipality's location may have. I take in Table 7 three additional approaches to provide further evidence on that distance to the capital is not behind the lordship effect. First, Panel A introduces a flexible (cubic) polynomial in distance to the capital city. The size of the coefficient slightly declines but remains negative and almost always statistically significant. Second, I use a subsample of municipalities in which distance to the capital city lies between 22 and 74 kilometers. For this subsample, the distribution of this variable is very similar in old lordship towns and the rest. The Kolmogorov-Smirnov test renders a highly insignificant p-value of 0.895 , indicating that the two distributions are very similar. Likewise, the mean difference in distance to the capital city is also highly insignificant for this subsample. Figure 2 compares the distribution for the full sample with that for the restricted sample, while Panel B (Table 7) reports the results. Reassuringly, the effect of lordship remains fairly robust. ${ }^{19}$ Third, Panel C includes very granular fixed effects in distance to the capital city (a set of 1-km-size bin dummies). This additional robustness check does not overturn the results.

Table 8 presents an adjacent-municipality analysis as the one conducted for the whole Spanish sample in Section 4.2. Odd columns report the unconditional differences between old lordships and the rest of municipalities, while even columns test these differences when differences in the observables are equal to zero (which is what the intercept captures). The results provide again support to the previous findings, being all the coefficients negative and most of the times statistically significant -although the lower number of observations decreases the statistical power.

To further exploit variation within small geographic areas, Table A7-Panel A (in Supplementary Material III) includes a set of 3 province dummies in Eq (2). The coefficient on lordship is slightly smaller in size but remains fairly robust. Panel B in the same table restricts the sample to municipalities with tax income data, which are those with more than 1,000 inhabitants in 2013, while Panel C deletes observations corresponding to newer lordships (those created after the first half of the $16^{\text {th }}$ century). The latter tries to address a potential concern with respect to the comparison group used in the regressions. So far in this section, old lordships are compared to the rest of municipalities, which include some towns that became lordships after the initial distribution of them. This is the right approach in my view, but for the sake of completeness I also report what happens when these late lordships are removed from the comparison group. The coefficient on lordship remains stable and always significant.

Finally, a potential confounding factor very difficult to measure is the presence of Morisco population. Moriscos could have left a deeper cultural legacy in old lordships, although this possibility is highly unlikely since they were massively expelled after the revolt in 1568 . Yet, it is possible that their (extractive) institutions persisted. Chaney and Hornbeck (2016) argue that Morisco lordships in Valencia were more extractive than Christian lordships, and there was persistence in the institutional framework after their expulsion in 1609. The case of

19 The range 22-74 kilometers is selected based on a simple algorithm which finds, among all possible ranges of kilometers in distance to the capital city, the one with the highest $p$-value in the KolmogorovSmirnov test of equality of distributions, provided that the resulting sample is at least half the size of the whole sample. 
Granada is however different in this regard. After their expulsion in the second half of the $16^{\text {th }}$ century, there was a second repopulation carefully monitored by the Crown. King Phillip II issued a specific regulation to organize the new resettlement of Granada (Muñoz Buendía, 1992). The newcomers did not suffer the bad conditions of Morisco times. The arrival of new settlers and the intervention of the King largely reduced the "feudal" rights of lords. "Both lords and settlers had to reach a high level of compromise, the former lowering their privileges regarding the Moorish period, and the latter adapting to the demands of the Lord" (Muñoz Buendía, 1992: 278, my translation). The repopulation of the last quarter of the $16^{\text {th }}$ century was thus a structural break in the seigneurial regime of Granada. "The pressure of the settlers, old Christians, supported by the Philippine administration, led to an important softening of the feudal subjection to which the Moorish vassals were subjected"; moreover, against the manorial abuses "there was always a powerful weapon left to the vassal, his legal right to leave, which would ruin seigneurial rents" (Muñoz Buendía, 1992: 279, my translation). ${ }^{20}$

\section{Mechanisms of persistence}

\subsection{Potential mechanisms}

This section discusses and investigates the channels by which lordships have negatively affected long-run development. There are several potential candidates. First, lordships can be considered an extractive institution imposing exactions and exerting monopolistic rights, which may distort economic incentives and the functioning of the local economy, with negative implications for the population's living conditions and long-run growth. This hypothesis is plausible although the Spanish historiography casts some doubts on its relevance. During the last century and a half of existence of the seigneurial regime, its extractive character became softer. Although there was heterogeneity across Spain, the fact is that seigneurial rents were a minor source of lords' income (Domínguez Ortiz, 1955). Nonetheless, it can be argued that the rights and prerogatives of lords could harm the development of the local economy, particularly when considering the distortions arising from monopolistic rights. Privileges rendering low income could be highly inefficient for society, producing a large reduction in welfare. In addition, the fact that the extractive character of the seigneurial regime in older times was higher could have long-term implications if it caused an early damage to the local economy, which can persist through a variety of factors (for instance, creating a bad reputation for a place, migration of skilled workers, etc.).

Second, lordships may have generated economic inequality, which is (increasingly) considered detrimental for economic growth (Galor et al., 2009; Oto-Peralías and RomeroÁvila, 2016). Although being the holder of jurisdictional rights did not imply landownership, it was common that lords were important landowners in their own lordships, particularly those of

20 The resettlement of the end of the $16^{\text {th }}$ century also introduced in rural communities the Castilian council, an important local government institution with a democratic character. "It is a model of council that clashes head-on against the old councils of towns and cities, dominated by an urban oligarchy [...] The creation of the council institution in all the repopulated places was rejected by cities and lords, because they saw in it a possible reduction in their jurisdictional powers" (Muñoz Buendía, 1992: 288-289, my translation). 
remote origins. The control of the local justice and the influence on the town council could also favor the accumulation of resources in the lords' hands. In this regard, it was not uncommon the usurpation of communal lands and acquisition of properties by fraudulent means. In addition, lords had incentives to expand their properties within their lordships, since their property rights would be better protected by the control of the local justice. It is worth noting, though, that the urban oligarchy increasingly became a decisive player at the local level and an important buyer of large estates (Soria Mesa, 1997).

Third, lordships, as a form of privatization of the local government, could have undermined state capacity in the municipality. In towns under noble jurisdiction the presence of the central government structure was arguably lower, and, compared to realengo towns, the effective control of the royal administration was also lower. Lords tried to avoid the application of central measures that were directly detrimental to them, or indirectly by affecting their vassals' fiscal capacity. For instance, lords were particularly against the collection of taxes in their lordships that did not provide any benefit to them. Relatedly, one "fiscal benefit" highly appreciated by vassals were not having to host royal troops in their homes. The law established that all towns were obliged to host troops but lords used their influence and connections with senior army officers to avoid it (Pérez Boyero, 1997). This protection by the lord undermined the capacity of the state to effectively impose its policies and regulations and was detrimental for neighboring towns. One of the representatives in the Cortes of 1625 argued that he was against the sale of jurisdictions "not because of the damage to them [the vassals] but to the others", since "it is known that conditions are softer in towns with noble jurisdiction than in royal places, where none stops the abuses of troops and none tries to reduce taxes as it happens in noble towns, where nobles use their influence to reduce the burden of villagers" (Domínguez Ortiz, 1964: 183, my translation). It is thus plausible that the privatization of the local government represented by lordship negatively affected state capacity, generating institutional traits that persisted over time. These traits could have undermined the capacity of the state to implement policies and its willingness to provide public goods in the municipality as well as the ability of the municipality to attract resources from the central government.

Finally, it is also possible, although slightly less plausible, that lordships affected development through a crowding-out effect of the Church. One reason may be competition for power and authority within the municipality. In municipalities under noble jurisdiction, the authority and influence of Catholic institutions to govern the local community could be lower. If religious institutions played a positive role in economic development, as found by some authors (Valencia Caicedo, 2015), a lower presence (or power) in a municipality could be detrimental for its long-run development. Another more prosaic reason has to do with money. Lay lords usually enjoyed some participation in the Church tithes (they owned approximately one fifth of them), which aimed to compensate lords for the duty of building and maintaining churches. Lords, however, were generally negligent observing this duty, with obvious negative implications for the provision of religious services and other religious activities (Domínguez Ortiz, 1955). 


\subsection{Empirical analysis}

What can be learned from the data about the relative importance of each channel? Regarding the extractive character of lordships, it is very difficult to measure, but I can take some indirect approaches to test it. Arguably, if the long-run negative effect of lordships is due to its extractive character, then the negative effect on the living conditions and local economy should be visible at the end of the Ancien Regime. With respect to the second channel (inequality), it can be measured through the percentage of daily workers over the active agricultural population in 1787 and through a more recent measure of land concentration. The state capacity channel can be accounted for through the percentage of state-related job occupations and a dummy variable capturing the presence of royal officials. I also use a dummy variable capturing whether there was a post office in the municipality in 1878 as an additional measure of state capacity. Finally, the presence of Catholic institutions can be measured through the percentage of secular and regular clergy over the total population. This analysis focuses on the Granadian sample for which I have a more exogenous variable of lordships.

Columns 1 to 4 in Table 9 use as dependent variables measures related to the level of economic development of the municipality at the end of the $18^{\text {th }}$ century, namely, (log) total population, $(\log )$ population density, percentage of labor force in agriculture, and percentage of labor force in occupations with low qualification. The coefficient on lordship is highly insignificant, suggesting that living conditions in lordships were not significantly worse than in realengo towns. ${ }^{21}$ Columns 5 and 6 use indicators of land inequality corresponding to the $18^{\text {th }}$ and the $20^{\text {th }}$ centuries. It seems that lordship is not associated with land inequality, indicating that inequality is not the channel that explains the current lower outcomes of former lordship towns. Column 7 and 8 employ two variables related to the presence of state-level employees in the municipality. Arguably, the state's infrastructural capacity is captured by these indicators, which are similar to others used in the literature (Acemoglu et al., 2015). Interestingly, the coefficient on lordship is negative and statistically significant, reducing the percentage of state-related job occupations in 0.24 standard deviations, and reducing the probability of having at least one royal official in 12 percentage points (which is a large effect given an average value of 0.55). Column 9 uses a post office dummy in 1878 as an alternative measure of historical state capacity. The coefficient is negative and highly statistically significant. Finally, the last two columns include indicators measuring the presence of secular and regular clergy. The coefficient on lordship is never negative and significant, indicating that its long-term negative effect is not mediated by a negative impact on religious institutions.

\subsection{Lordships and state capacity}

The evidence from Table 9 indicates that state capacity appears to be a relevant channel to

${ }^{21}$ The lack of a statistically significant relationship between lordship and population in 1787 rules out the concern about the possibility that lordships were initially minor towns and its negative relationship with current outcomes would simply reflect their lower size relative to (supposedly bigger) royal towns. Hence, these insignificant coefficients strongly suggest that the negative effect of lordship is not driven by initial differences in population size with respect to royal towns. 
explain the negative effect of lordship on current outcomes. Its plausibility as a relevant channel would be more convincing if there also exists a significant relationship between the presence of state officials in the $18^{\text {th }}$ century and current economic outcomes. Table A8 in Supplementary Material III shows that this is the case: both the percentage of state-related job occupations and the royal employee dummy are positive and significantly correlated with income, light emission at night and the other current outcome variables. Therefore, historical state capacity seems to be a relevant predictor of local economic development, which is in line with the extant literature (Acemoglu et al., 2015, 2016; Dell et al., 2017). It is worth stressing that I am considering the capacity of the central state in the municipality, while other works focus more on local state capacity (Acemoglu et al., 2015; Dell et al., 2017)

A further important question to ask is why and how historical state capacity matters. My hypothesis is that lordship, by undermining the presence of the state as well as the application of government policies in the municipality, has historically weakened: i) the capacity of the state to implement policies in the municipality, ii) the willingness of the state to build public infrastructure and provide other public goods, and iii) the ability of the municipality to attract resources from the central government. ${ }^{22}$

The lack of a negative impact of lordship on $18^{\text {th }}$-century outcomes suggests that the intervening role of state capacity has taken place afterwards, which is consistent with my hypothesis. The weak link of lordships with the royal administration in the Ancien Regime could have advantages then when the central government was seen as an extractor of resources, but since the $19^{\text {th }}$ and particularly the $20^{\text {th }}$ century, the central government has increasingly played an active role promoting economic development through investments in infrastructure and human capital. In addition, state capacity to build infrastructure and create a homogeneous institutional framework becomes particularly important when economies transit to the industrial and service sectors, that is, with the arrival of new productive systems and technologies. The weak historical link of lordships with the central state, reflected by a lower presence of royal employees, could have persisted over time with negative implications for the development of public infrastructures and other public goods.

The previous result about the lower probability of a post office in old lordships (column 9, Table 9) illustrates well the mechanism of persistence. The post service is an early public service that reflects well the presence of the state's infrastructural capacity and had important effects on economic activity (Acemoglu et al. 2016). The post service (Correos) was a royal service since the beginning of the $18^{\text {th }}$ century. The evidence indicates that the Crown preferred royal towns to establish post offices. Thus, early in the $19^{\text {th }}$ century, there were two main and ten secondary post office administrations in the former Kingdom of Granada and, among all of them, only one secondary administration was located in a lordship (data from de Cabanes, 1830). In the mid-19 ${ }^{\text {th }}$ century, right after the abolition of the seigneurial regime in

${ }^{22}$ In addition, another plausible hypothesis is that lordship, by undermining historical state capacity, could have favored the creation of a culture of lack of trust, confidence and cooperation with state-level institutions. This could have affected, in turn, the application of national policies and the provision of public goods. However, lack of survey data at the municipality level makes it very difficult to test this hypothesis. Using data on voter turnout I find no evidence of a negative effect of lordships on participation in local, regional or general elections. 
Spain, there were 67 post offices (including smaller offices, carterias) in the region. The percentage of former royal towns with post offices was almost twice as large as that of former lordships (21.6 vs 12.26\%). In 1878 the number of post offices increased to 82 but the difference between former royal and lordship towns persisted (26.4 vs 15.09\%). The unconditional difference of 11.31 (i.e., 26.4-15.09) is actually smaller than the difference when controlling for the baseline set of geographic and locational controls (13.5). This indicates that half a century after the dismantlement of the old regime, there was a clear persistence in the presence of the central state in municipalities. ${ }^{23}$

Finally, Table 10 provides further evidence consistent with my hypothesis by analyzing the relationship of lordship with the provision of public goods today and the presence of the regional government in the municipality. Old lordships are associated with a lower provision of public goods (kindergartens, roads in good conditions and broadband infrastructure) and with less presence of Andalusian government's employees. Table A9 shows that there is also a strong relationship, in this case positive, between the indicators of state capacity in 1787 and the proxies for modern-day state capacity.

To sum up, the evidence provided in this section points to state capacity as an important channel through which lordship has negatively affected long-run development. Other factors such as the extractive character of lordships, economic inequality and the Church do not appear to be relevant channels, although measurement errors and lack of data availability prevent any attempt to completely rule out any of these (or other) potential mechanisms.

\section{Conclusions}

This paper investigates the long-term consequences of delegation of governmental authority through the study of a pivotal local political institution in historical Europe: the lordship. I collect data on seigneurial rights for ancien-regime Spain and document a negative relationship between $18^{\text {th }}$-century seigneurial jurisdictions and current economic development at the municipality level for the whole country. To shed light on the causal effect, I study the distribution of lordships in the former Kingdom of Granada after its conquest by the Catholic Monarchs, which can be taken as conditionally random. The results confirm the negative effect of lordship found for the whole country: towns that shortly after the conquest were granted to nobles are relatively poorer today. The negative effect of lordship is robust both in a standard regression framework with region fixed effects and when comparing adjacent municipalities.

To explore how the effect has taken place, I analyze factors that may have played an intermediating role, with the results pointing to lower state capacity as a main factor explaining the long-term negative effect of lordship on development. This finding is consistent with an interpretation of seigneurial jurisdictions as a privatization of the local government, which has historically weakened the link with the central administration and hindered the application of central government policies and the ability of municipalities to attract

\footnotetext{
${ }^{23}$ Relatedly, the central state presence in 1787 is a very strong predictor of the existence of post offices a century later. Having royal employees in 1787 increases the probability of having a post office by 26 percentage points (or 21 percentage points more when including the set of control variables). Results available upon request.
} 
government investments. The analysis also shows that lordship had not negatively affected economic development by the end of the Ancien Regime but there was already evidence of lower state's infrastructural capacity at that time. This suggests an evolving role of state capacity. Before industrialization, when the main economic sector is agriculture, the central government was seen as an extractor of resources and the public goods it provided -such as national defense- only had an indirect effect on the local economy. In such a context, weak state capacity in a municipality was not necessarily negative for local economic development. On the contrary, it could even have some positive effects by lowering the state's tax burden and protecting the population from repressive institutions such as the Inquisition and from army conscription. However, with the expansion of the secondary and tertiary sectors, central governments started to play a more active role promoting economic development through investments in infrastructure, education and the provision of other public goods and services highly complementary to the new economic activities. This made state capacity a valuable asset for economic development in sharp contrast to the previous situation.

This paper thus contributes to the vibrant literature on the effect of local political institutions on economic development and the role played by state capacity (Iyer, 2010; Michalopoulos and Papaioannou, 2013; Acemoglu et al., 2015, 2016; Dell et al., 2017). This is to my knowledge the first attempt to empirically study the economic consequences of lordships, an institution not only important for medieval and modern Europe but also for other parts of the world and historical periods. An analysis of lordships, as an instance of privatization of local governmental functions, can inform research on other recurrent phenomena in which the central state delegates functions and powers to private agents. In addition, this paper sheds new light on channels of persistence. The presence of the state's infrastructural power is an institutional feature that persists over time. It is a mechanism independent of the cultural one, which has been highlighted in the recent literature (Guiso et al., 2016; Dell et al., 2017). Finally, the article also provides evidence suggesting an evolving role of state capacity over time, which becomes more decisive for development after the industrial revolution. 


\section{References}

Acemoglu, Daron, and Alexander Wolitzky. 2011. "The Economics of Labor Coercion." Econometrica 79.2 (2011): 555-600.

Acemoglu, Daron, Tristan Reed, and James A. Robinson. 2014. "Chiefs: Economic development and elite control of civil society in Sierra Leone." Journal of Political Economy 122.2: 319-368.

Acemoglu, Daron, Camilo García-Jimeno, and James A. Robinson. 2015. "State Capacity and Economic Development: A Network Approach." American Economic Review, 105(8): 2364-2409.

Acemoglu, Daron, Jacob Moscona, and James A. Robinson. 2016. "State capacity and American technology: evidence from the nineteenth century." American Economic Review 106.5: 61-67.

Angelucci, Charles, Simone Meraglia, and Nico Voigtländer. 2017. "The Medieval Roots of Inclusive Institutions: From the Norman Conquest of England to the Great Reform Act." National Bureau of Economic Research, No. w23606.

Ashraf, Quamrul H., Francesco Cinnirella, Oded Galor, Boris Gershman, and Erik Hornung. 2017. "Capital-skill complementarity and the emergence of labor emancipation." Working paper.

Birriel Salcedo, Margarita and Enrique Soria Mesa. 1993. "Notas sobre los señoríos del reino de Granada: siglos XV-XVIII", In (eds. Eliseo Serrano and Esteban Sarasa) Señorío y Feudalismo en la Península Ibérica (siglos XII-XIX), Zaragoza: Institución Fernando el Católico, p. 129-173.

Bruhn, Miriam, and Francisco A. Gallego. 2012. "Good, bad, and ugly colonial activities: do they matter for economic development?" Review of Economics and Statistics 94.2: 433-461.

Cabrera Muñoz, Emilio. 2004. "Conflictos en el mundo rural: señores y vasallos". Conflictos sociales, políticos e intelectuales en la España de los siglos XIV y XV : XIV Semana de Estudios Medievales , p. 49-80. Logroño: Instituto de Estudios Riojanos.

Chaney, Eric, and Richard Hornbeck. 2016. "Economic dynamics in the Malthusian era: evidence from the 1609 Spanish expulsion of the Moriscos." The Economic Journal 126 (594): 1404-1440.

Conley, Timothy. 1999. "GMM Estimation with Cross Sectional Dependence." Journal of Econometrics 92: 1-45.

de Cabanes, Francisco Xavier. 1830. Guía General de Correos, Postas y Caminos del Reino de España. Madrid: Imprenta de D. Miguel de Burgos.

Dell, Melissa. 2010. "The persistent effects of Peru's mining mita." Econometrica 78.6: 1863-1903.

Dell, Melissa, Nathaniel Lane, and Pablo Querubin. 2017. "The historical state, local collective action, and economic development in Vietnam." Econometrica, forthcoming.

Dewald, Jonathan. 1996. The European Nobility, 1400-1800. New York: Cambridge University Press.

Domínguez Ortiz, Antonio. 1955. La Sociedad Española del Siglo XVIII. Madrid: CISC.

Domínguez Ortiz, Antonio. 1964. "Ventas y exenciones de lugares durante el reinado de Felipe IV." Anuario de historia del derecho español 34: 163-208.

Fourquin, Guy. 1976. Lordship and Feudalism in the Middle Ages. London: Allen and Unwin. 
Galor, Oded, Omer Moav, and Dietrich Vollrath. 2009. "Inequality in landownership, the emergence of human-capital promoting institutions, and the great divergence." The Review of Economic Studies 76.1: 143-179.

Garzón Pareja, Manuel. 1977. "Señoríos del reino de Granada." Boletín de la Real Academia de la Historia, T. CLXXIV: 571-636.

Gennaioli, Nicola, and Ilia Rainer. 2007. "The modern impact of precolonial centralization in Africa." Journal of Economic Growth 12.3, 185-234.

González Alonso, Benjamín. 1983, "Notas sobre las relaciones del estado en la administración señorial en la Castilla moderna", Anuario de Historia del Derecho Español 53: 366-395.

Guardado, Jenny. 2017. "Office-Selling. Corruption and Long-Term Development in Peru." Working Paper.

Guilarte, Alfonso M. 1987. El Régimen Señorial en el Siglo XVI. Valladolid: Universidad de Valladolid.

Guiso, Luigi, Paola Sapienza, and Luigi Zingales. 2016. "Long-term persistence." Journal of the European Economic Association 14.6: 1401-1436.

Instituto Geográfico Nacional. 2013. Archivos de Polígonos de Municipios de Líneas Límite del Área del Registro Central de Cartografía. http://www.ign.es

Instituto Nacional de Estadística (INE). 1987-1991. Censo de 1787 "Floridablanca". Vols I to VI. Madrid: Instituto Nacional de Estadística.

Iyer, Lakshmi. 2010. "Direct versus indirect colonial rule in India: Long-term consequences." The Review of Economics and Statistics 92.4: 693-713.

Klein, Alexander and Ogilvie, Sheilagh. 2017. "Was Domar Right? Serfdom and Factor Endowments in Bohemia". London, Centre for Economic Policy Research.

Lange, Matthew. 2009. Lineages of Despotism and Development: British Colonialism and State Power. Chicago: University of Chicago Press.

Ladero Quesada, Miguel A. 1979. Granada : historia de un pass islámico, (1232-1571). Madrid: Gredos.

Ladero Quesada, Miguel A. 1968. "La Repoblación del Reino de Granada anterior al año 1500." Hispania, 28: 110.

Laredo Quesada, Miguel A. 1989. Los Reyes Católicos: La Corona y la Unidad de España. Valencia: Asociación Francisco López de Gomara, DL.

López de Coca, José Enrique. 1993. "Los señoríos del reino de Granada (1490-1568). Introducción a su estudio." In (eds. Eliseo Serrano and Esteban Sarasa) Señorío y Feudalismo en la Península Ibérica (siglos XII-XIX). Zaragoza: Institución Fernando el Católico, p. 129-173.

Markevich, Andrei, and Ekaterina Zhuravskaya. 2018. "The Economic Effects of the Abolition of Serfdom: Evidence from the Russian Empire." American Economic Review, forthcoming.

Michalopoulos, Stelios. 2012. "The origins of ethnolinguistic diversity." The American Economic Review 102 (4): 1508-1539. 
Michalopoulos, Stelios, and Elias Papaioannou. 2013. "Pre-colonial ethnic institutions and contemporary African development." Econometrica 81.1: 113-152.

Moxó, Salvador de. 1964. "Los señoríos. En torno a una problemática para el estudio del régimen señorial." Hispania 24.94: 185.

Muñoz Buendía, Antonio. 1992. "La Repoblación del Reino de Granada a Finales del Quinientos: Las Instrucciones Particulares de 1595. I. Estudio" Chronica Nova, 20: 253-297.

Nader, Helen. 1990. Liberty in Absolutist Spain: The Habsburg Sale of Towns, 1516-1700. Baltimore: Johns Hopkins University Press.

North, Douglass C. 1991. "Institutions" The Journal of Economic Perspectives 5.1: 97-112.

Ogilvie, Sheilagh, and André W. Carus. 2014. "Institutions and economic growth in historical perspective." Handbook of economic growth. Vol. 2. Elsevier. 403-513.

Oto-Peralías, Daniel, and Romero-Ávila, Diego. 2014. "The distribution of legal traditions around the world: a contribution to the legal-origins theory." The Journal of Law and Economics, 57(3), 561-628.

Oto-Peralías, Daniel, and Diego Romero-Ávila. 2016. "The Economic Consequences of the Spanish Reconquest: The Long-term Effects of Medieval Conquest and Colonization." Journal of Economic Growth 21: 409-464.

Oto-Peralías, Daniel, and Diego Romero-Ávila. 2017. "Historical Frontiers and the Rise of Inequality: The Case of the Frontier of Granada," Journal of the European Economic Association 15 (1): 54-98.

Pérez Boyero, Enrique. 1997. Moriscos y cristianos en los señoríos del Reino de Granada (14901568). Granada: Universidad de Granada.

Pérez Moreda, Vicente. 2010. "La estadística demográfica en el gobierno de la España ilustrada: recuerdo y elogio del Censo de Floridablanca." Indice: Revista de estadística y sociedad, 43: 8-17.

Peinado, Rafael G. 2011. "El reino de Granada tras la conquista castellana." XXXVIII Semana de Estudios Medievales. Separata, p. 27-94.

Ravina, Mark. 1999. Land and Lordship in Early Modern Japan. Stanford: Stanford University Press.

Ruiz, Teofilo. 1998. "The Peasantries of Iberia." In (Scott, Tom, ed.) The peasantries of Europe: from the fourteenth to the eighteenth centuries. Longman Publishing Group, p. 49-74.

Segura Graiño, Cristina. 1982. "Realengo y Señorío en la tierra de Almería en el siglo XV." En la España Medieval, 3: 595-595.

Shannon, William D. 2012. "The Survival of True Intercommoning in Lancashire in the EarlyModern Period," Agricultural History 86(4): 169-191.

Sharma, Ram Sharan. 2003. Early Medieval Indian Society: A Study in Feudalisation. Hyderabad : Orient Blackswan.

Soria Mesa, Enrique. 1997. Señores y oligarcas: los señoríos del Reino de Granada en la Edad Moderna. Granada: Universidad de Granada. 
Valencia Caicedo, Felipe. 2015. "The mission: Human capital transmission, economic persistence and culture in South America." Working Paper.

Valdeón Baruque, Julio. 1997. "Señoríos y nobleza en la Baja Edad Media (El ejemplo de la Corona de Castilla)" Revista d'historia medieval, 8: 15-24.

Vassberg, David E. 1984. Land and Society in Golden Age Castile. Cambridge: Cambridge University Press. 


\section{Figures and tables}

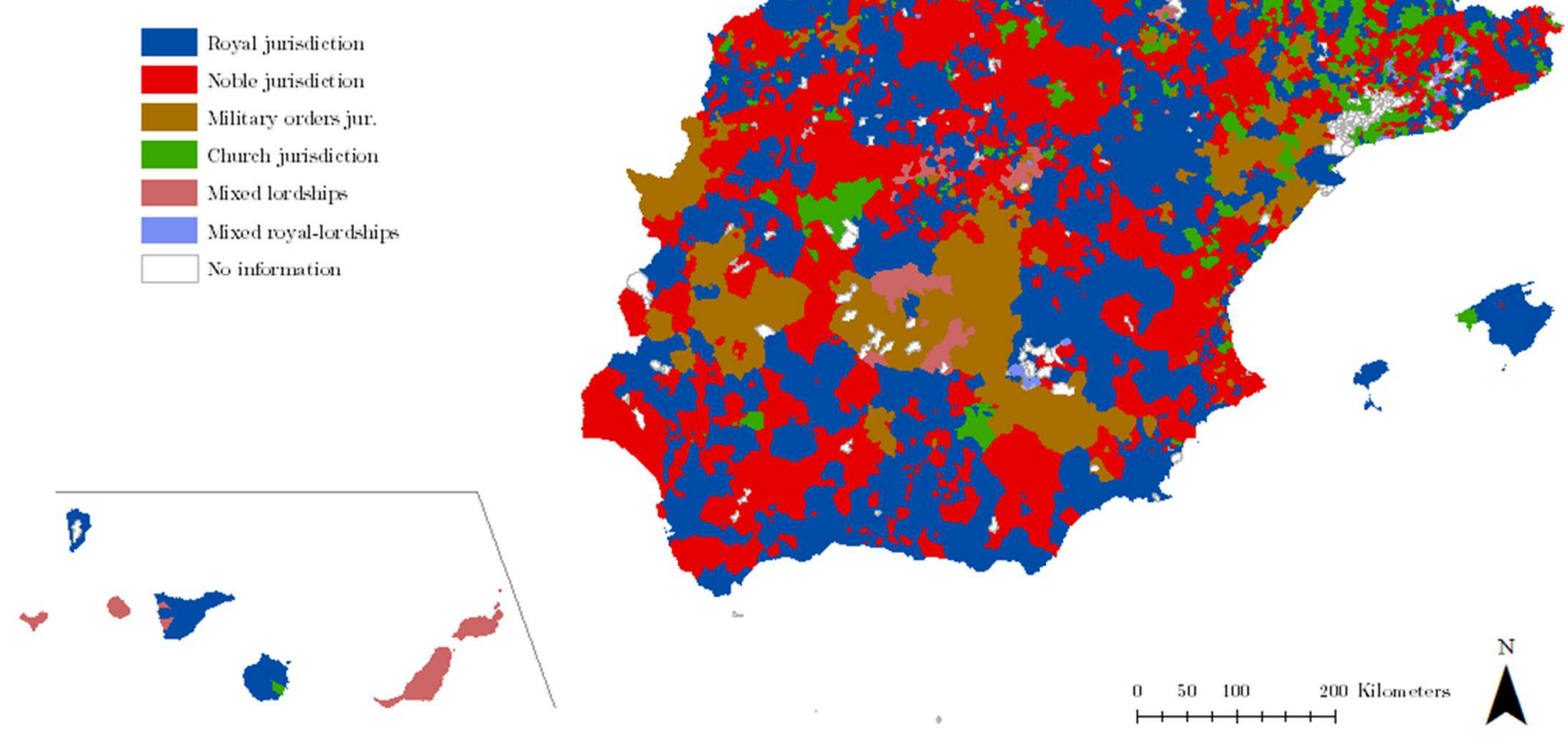

Figure 1. The distribution of types of jurisdiction in 1787 


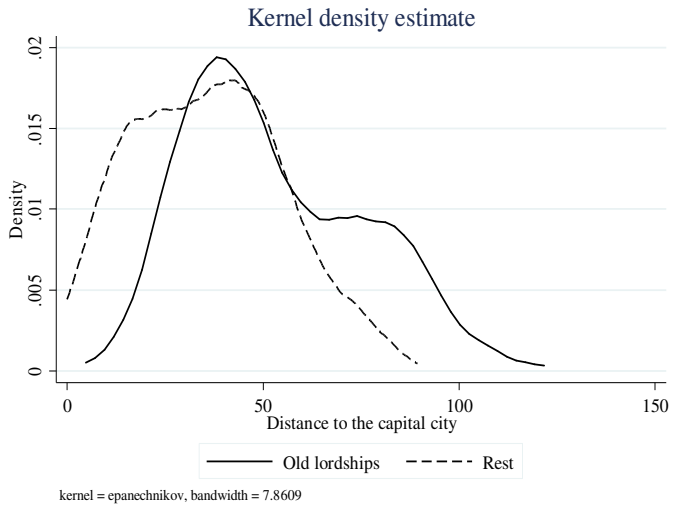

A. Full sample

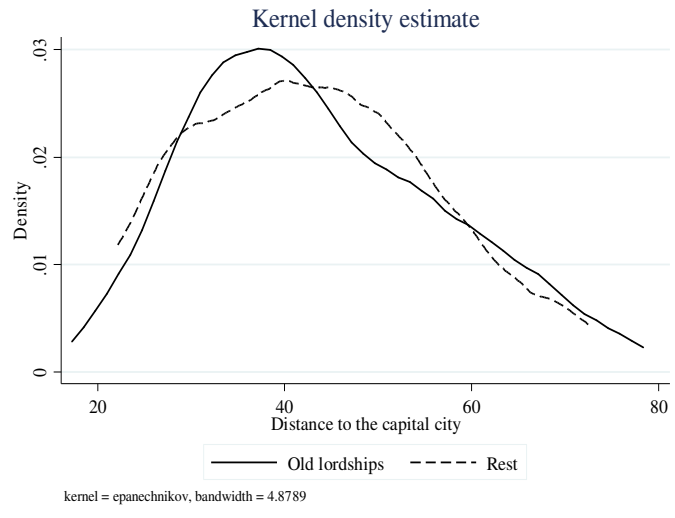

B. Subsample with a similar distribution: between 22 and $74 \mathrm{~km}$ from the capital city

Figure 2. Subsample of municipalities with a similar distribution in distance to the capital city 
Table 1. Distribution of settlements and municipalities by jurisdictional status in 1787

\begin{tabular}{lccccc}
\hline & $\begin{array}{c}\text { Population } \\
\text { entities in 1787 }\end{array}$ & $\begin{array}{c}\text { Current } \\
\text { municipalities }\end{array}$ & $\begin{array}{c}\text { Population in } \\
1787\end{array}$ & $\begin{array}{c}\text { Population in } \\
2001\end{array}$ & Surface area \\
\cline { 2 - 5 } Noble & $43 \%$ & $44 \%$ & $34 \%$ & $22 \%$ & $39 \%$ \\
Royal & $36 \%$ & $37 \%$ & $46 \%$ & $63 \%$ & $39 \%$ \\
Church & $13 \%$ & $8 \%$ & $10 \%$ & $7 \%$ & $7 \%$ \\
Military orders & $3 \%$ & $6 \%$ & $7 \%$ & $4 \%$ & $11 \%$ \\
Lordship (mixed) & $2 \%$ & $2 \%$ & $2 \%$ & $2 \%$ & $2 \%$ \\
Royal and lordship (mixed) & $1 \%$ & $1 \%$ & $1 \%$ & $1 \%$ & $0 \%$ \\
Missing data & $2 \%$ & $3 \%$ & $1 \%$ & $2 \%$ & $2 \%$ \\
Total & 20,197 & 8,115 & $10,413,198$ & $40,703,749$ & 504,465 \\
\hline
\end{tabular}

Notes: Variables' descriptions are provided in Table A1.

Table 2. Balancedness analysis of lordships

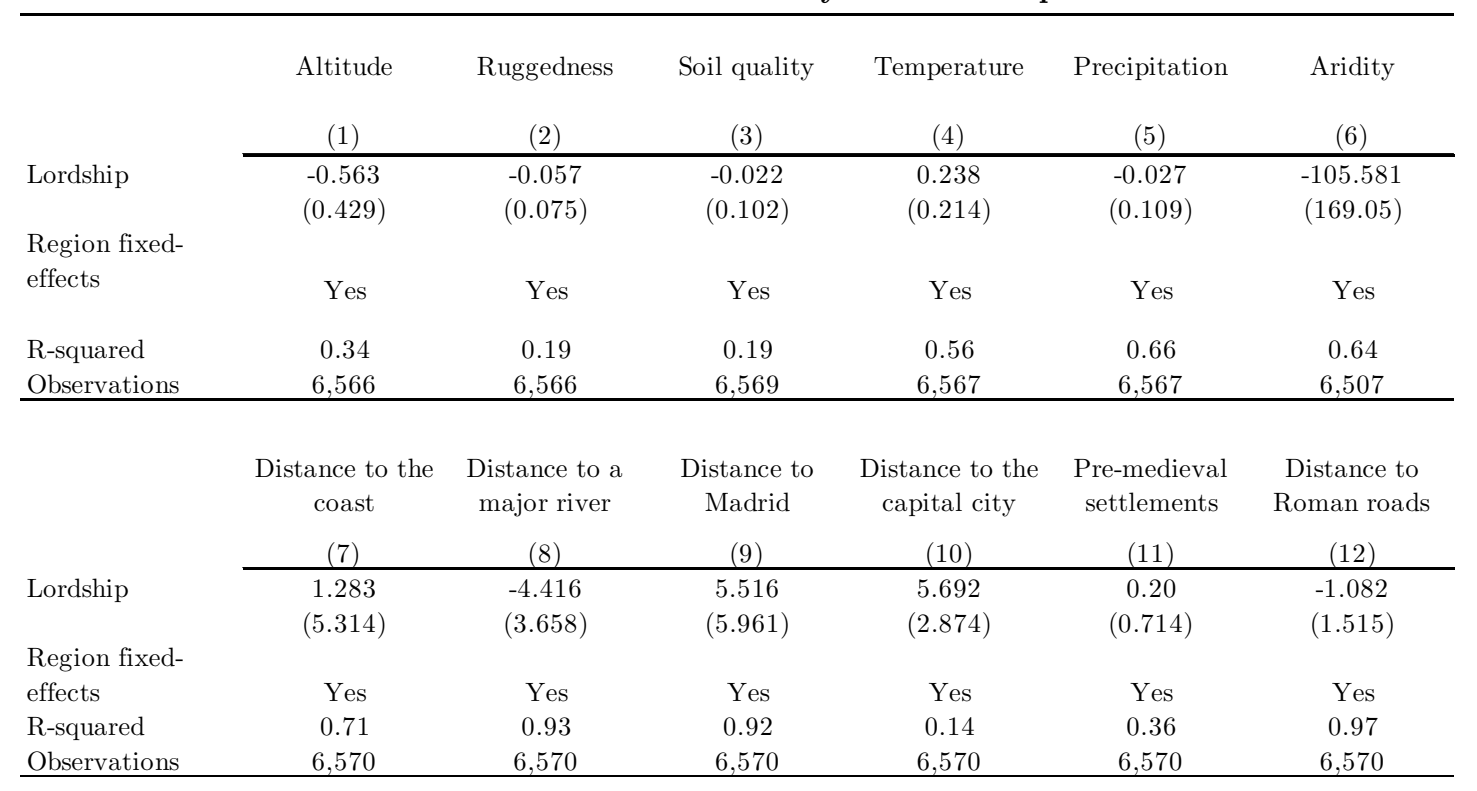

Notes: Variables' descriptions are provided in Table A1. Regressions include a constant term which is omitted for space considerations. Standard errors clustered at the region level are in parentheses. 
Table 3. Lordships and modern-day economic development

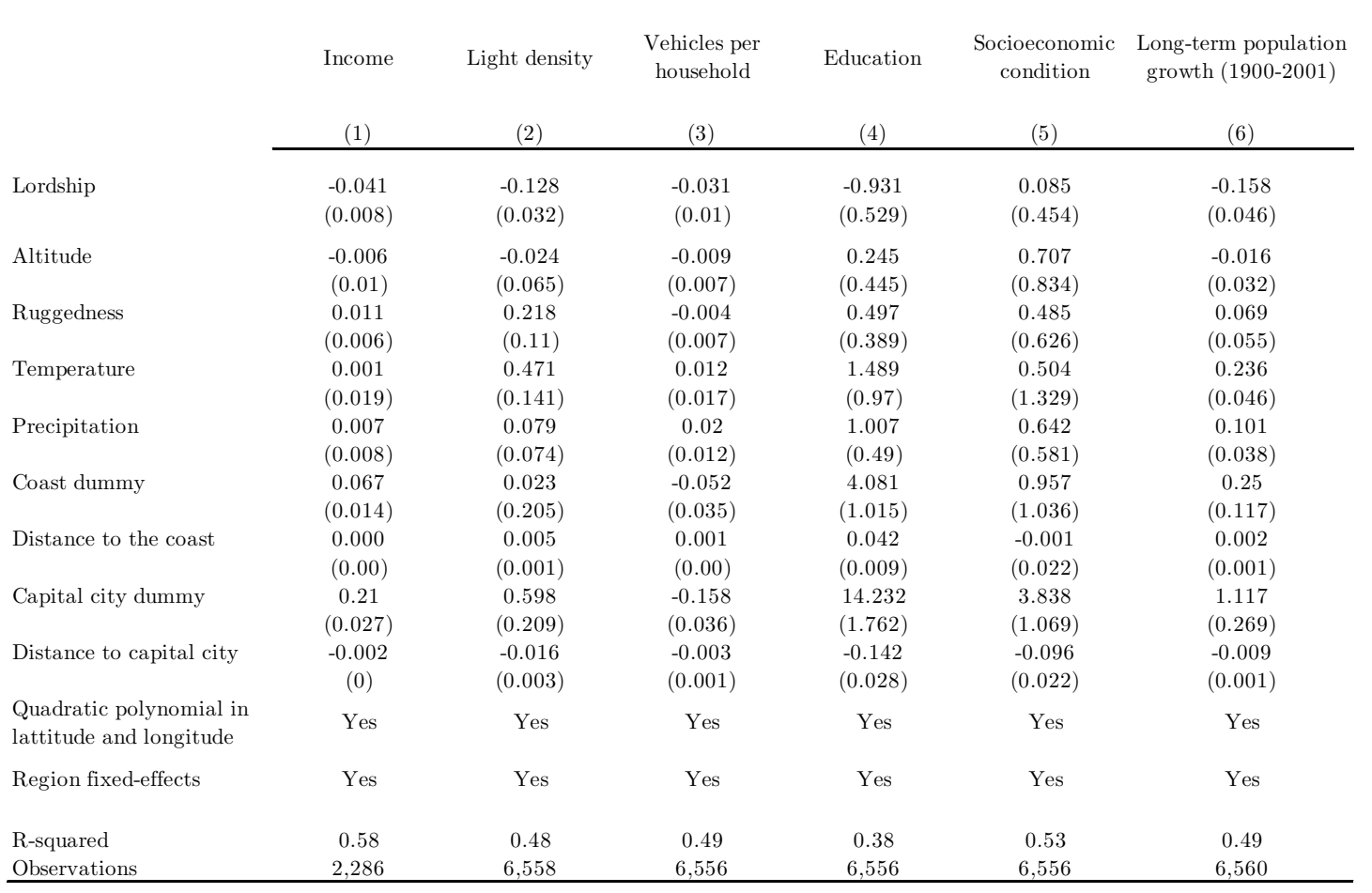

Notes: Variables' descriptions are provided in Table A1. Regressions include a constant term which is omitted for space considerations. Standard errors clustered at the region level are in parentheses. 
Table 4. Adjacent municipalities analysis

\begin{tabular}{|c|c|c|c|c|c|c|}
\hline & \multicolumn{2}{|c|}{ Income } & \multicolumn{2}{|c|}{ Light density } & \multicolumn{2}{|c|}{ Vehicles per household } \\
\hline & $(1)$ & $(2)$ & $(3)$ & $(4)$ & $(5)$ & $(6)$ \\
\hline $\begin{array}{l}\text { Difference between lordship } \\
\text { and royal jurisdiction }\end{array}$ & $\begin{array}{l}-0.037 \\
(0.009)\end{array}$ & $\begin{array}{l}-0.033 \\
(0.006)\end{array}$ & $\begin{array}{l}-0.148 \\
(0.037)\end{array}$ & $\begin{array}{l}-0.122 \\
(0.03)\end{array}$ & $\begin{array}{c}0.000 \\
(0.011)\end{array}$ & $\begin{array}{l}0.001 \\
(0.01)\end{array}$ \\
\hline $\begin{array}{l}\text { Differences in control } \\
\text { variables included }\end{array}$ & No & Yes & No & Yes & No & Yes \\
\hline R-squared & 0.00 & 0.09 & 0.00 & 0.09 & 0.00 & 0.02 \\
\hline \multirow[t]{3}{*}{ Observations } & 703 & 703 & 2,385 & 2,385 & 2,388 & 2,387 \\
\hline & \multicolumn{2}{|c|}{ Education } & \multicolumn{2}{|c|}{ Socioeconomic condition } & \multicolumn{2}{|c|}{$\begin{array}{l}\text { Long-term population } \\
\text { growth }(1900-2001)\end{array}$} \\
\hline & $(7)$ & $(8)$ & $(9)$ & $(10)$ & $(11)$ & $(12)$ \\
\hline $\begin{array}{l}\text { Difference between lordship } \\
\text { and royal jurisdiction }\end{array}$ & $\begin{array}{l}-1.079 \\
(0.389)\end{array}$ & $\begin{array}{l}-0.762 \\
(0.406)\end{array}$ & $\begin{array}{l}-0.392 \\
(0.367)\end{array}$ & $\begin{array}{l}-0.270 \\
(0.384)\end{array}$ & $\begin{array}{l}-0.120 \\
(0.031)\end{array}$ & $\begin{array}{l}-0.101 \\
(0.034)\end{array}$ \\
\hline $\begin{array}{l}\text { Differences in control } \\
\text { variables included }\end{array}$ & No & Yes & No & Yes & No & Yes \\
\hline R-squared & 0.00 & 0.02 & 0.00 & 0.01 & 0.00 & 0.09 \\
\hline Observations & 2,388 & 2,387 & 2,388 & 2,387 & 2,388 & 2,387 \\
\hline
\end{tabular}

Notes: Variables' descriptions are provided in Table A1. The table reports the coefficient on the constant term from regressions in which the dependent variables measure the difference between each lordship municipality and a comparison group of neighboring royal towns. Standard errors clustered at the region level are in parentheses. 
Table 5. Balancedness analysis of Granadian lordships

\begin{tabular}{|c|c|c|c|c|c|c|}
\hline & Altitude & Ruggedness & Soil quality & Temperature & Precipitation & Aridity \\
\hline & $(1)$ & $(2)$ & $(3)$ & $(4)$ & $(5)$ & $(6)$ \\
\hline Old lordship & $\begin{array}{c}0.897 \\
(0.683)\end{array}$ & $\begin{array}{c}0.234 \\
(0.199)\end{array}$ & $\begin{array}{l}-0.248 \\
(0.151)\end{array}$ & $\begin{array}{l}-0.577 \\
(0.331)\end{array}$ & $\begin{array}{c}0.018 \\
(0.338)\end{array}$ & $\begin{array}{c}115.364 \\
(320.053)\end{array}$ \\
\hline R-squared & 0.01 & 0.01 & 0.02 & 0.02 & 0.00 & 0.00 \\
\hline \multirow[t]{2}{*}{ Observations } & 356 & 356 & 356 & 356 & 356 & 356 \\
\hline & $\begin{array}{c}\text { Distance to the } \\
\text { coast } \\
(7) \\
\end{array}$ & $\begin{array}{c}\text { Distance to a } \\
\text { major river } \\
(8)\end{array}$ & $\begin{array}{c}\text { Distance to } \\
\text { Madrid } \\
(9) \\
\end{array}$ & $\begin{array}{c}\text { Distance to the } \\
\text { capital city } \\
(10)\end{array}$ & $\begin{array}{c}\text { Distance to } \\
\text { Roman roads } \\
(11)\end{array}$ & $\begin{array}{c}\text { Pre-medieval } \\
\text { settlements } \\
(12) \\
\end{array}$ \\
\hline Old lordship & $\begin{array}{l}6.095 \\
(5.261)\end{array}$ & $\begin{array}{c}-11.464 \\
(4.835)\end{array}$ & $\begin{array}{c}-2.549 \\
(10.583)\end{array}$ & $\begin{array}{l}17.303 \\
(6.075)\end{array}$ & $\begin{array}{c}-3.706 \\
(4.289)\end{array}$ & $\begin{array}{c}0.068 \\
(0.887)\end{array}$ \\
\hline R-squared & 0.01 & 0.04 & 0.00 & 0.13 & 0.02 & 0.00 \\
\hline Observations & 356 & 356 & 356 & 356 & 356 & 356 \\
\hline
\end{tabular}

Table 6. Lordships and modern-day economic development: Former Kingdom of Granada

\begin{tabular}{lcccccc}
\hline & Income & Light density & $\begin{array}{c}\text { Vehicles per } \\
\text { household }\end{array}$ & Education & $\begin{array}{c}\text { Socioeconomic } \\
\text { condition }\end{array}$ & $\begin{array}{c}\text { Long-term population } \\
\text { growth (1900-2001) }\end{array}$ \\
\cline { 2 - 6 } & $(1)$ & $(2)$ & $(3)$ & $(4)$ & $(5)$ & $(6)$ \\
\hline Old lordship & -0.078 & -0.655 & -0.085 & -4.148 & -3.383 & -0.518 \\
& $(0.027)$ & $(0.142)$ & $(0.027)$ & $(1.969)$ & $(1.163)$ & Yes \\
$\begin{array}{l}\text { Geographic and climatic } \\
\text { controls }\end{array}$ & Yes & Yes & Yes & Yes & Yes & Yes \\
$\begin{array}{l}\text { Quadratic polynomial in } \\
\text { lattitude and longitude }\end{array}$ & Yes & Yes & Yes & Yes & Yes & 0.45 \\
R-squared & 0.40 & 0.57 & 0.41 & 0.29 & 0.41 & 356 \\
Observations & 217 & 356 & 356 & 356 & 356 & \\
\hline
\end{tabular}

Notes: Variables' descriptions are provided in Table A1. The geographic and climatic controls include altitude, ruggedness, temperature, precipitation, coast dummy, distance to the coast, capital city dummy, and distance to the capital city. Regressions include a constant term which is omitted for space considerations. Standard errors corrected for spatial dependence are in parentheses. 
Table 7. Lordships and modern-day economic development: Former Kingdom of Granada: Robustness checks

\begin{tabular}{|c|c|c|c|c|c|c|}
\hline & $\begin{array}{c}\text { Income } \\
(1) \\
\end{array}$ & Light density & $\begin{array}{l}\text { Vehicles per } \\
\text { household } \\
(3) \\
\end{array}$ & $\begin{array}{c}\text { Education } \\
\\
(4)\end{array}$ & $\begin{array}{c}\text { Socioeconomic } \\
\text { condition } \\
(5) \\
\end{array}$ & $\begin{array}{l}\text { Long-term population } \\
\text { growth (1900-2001) } \\
(6) \\
\end{array}$ \\
\hline \multicolumn{7}{|c|}{ Panel A) Cubic polynomial in distance to the capital city } \\
\hline Old lordship & $\begin{array}{l}-0.068 \\
(0.028)\end{array}$ & $\begin{array}{l}-0.499 \\
(0.101)\end{array}$ & $\begin{array}{l}-0.054 \\
(0.019)\end{array}$ & $\begin{array}{l}-2.381 \\
(1.662)\end{array}$ & $\begin{array}{l}-2.226 \\
(1.043)\end{array}$ & $\begin{array}{l}-0.408 \\
(0.082)\end{array}$ \\
\hline $\begin{array}{l}\text { Geographic and climatic } \\
\text { controls }\end{array}$ & Yes & Yes & Yes & Yes & Yes & Yes \\
\hline $\begin{array}{l}\text { Quadratic polynomial in } \\
\text { lattitude and longitude }\end{array}$ & Yes & Yes & Yes & Yes & Yes & Yes \\
\hline $\begin{array}{l}\text { R-squared } \\
\text { Observations }\end{array}$ & $\begin{array}{l}0.48 \\
217\end{array}$ & $\begin{array}{l}0.63 \\
356\end{array}$ & $\begin{array}{c}0.50 \\
356\end{array}$ & $\begin{array}{l}0.37 \\
356\end{array}$ & $\begin{array}{l}0.45 \\
356\end{array}$ & $\begin{array}{l}0.49 \\
356\end{array}$ \\
\hline \multicolumn{7}{|c|}{ Panel B) Subsample with a similar distribution in distance to the capital city } \\
\hline Old lordship & $\begin{array}{l}-0.056 \\
(0.024)\end{array}$ & $\begin{array}{l}-0.582 \\
(0.118)\end{array}$ & $\begin{array}{l}-0.051 \\
(0.021)\end{array}$ & $\begin{array}{l}-2.875 \\
(1.712)\end{array}$ & $\begin{array}{l}-2.928 \\
(1.139)\end{array}$ & $\begin{array}{l}-0.429 \\
(0.079)\end{array}$ \\
\hline $\begin{array}{l}\text { Geographic and climatic } \\
\text { controls }\end{array}$ & Yes & Yes & Yes & Yes & Yes & Yes \\
\hline $\begin{array}{l}\text { Quadratic polynomial in } \\
\text { lattitude and longitude }\end{array}$ & Yes & Yes & Yes & Yes & Yes & Yes \\
\hline $\begin{array}{l}\text { R-squared } \\
\text { Observations }\end{array}$ & $\begin{array}{r}0.50 \\
134\end{array}$ & $\begin{array}{l}0.52 \\
251\end{array}$ & $\begin{array}{l}0.44 \\
251\end{array}$ & $\begin{array}{l}0.28 \\
251\end{array}$ & $\begin{array}{l}0.52 \\
251\end{array}$ & $\begin{array}{c}0.44 \\
251\end{array}$ \\
\hline \multicolumn{7}{|c|}{ Panel C) Very granular 1-km distance fixed effects } \\
\hline Old lordship & $\begin{array}{l}-0.064 \\
(0.029)\end{array}$ & $\begin{array}{r}-0.509 \\
(0.09)\end{array}$ & $\begin{array}{l}-0.065 \\
(0.022)\end{array}$ & $\begin{array}{l}-2.230 \\
(1.556)\end{array}$ & $\begin{array}{l}-2.978 \\
(0.638)\end{array}$ & $\begin{array}{l}-0.345 \\
(0.109)\end{array}$ \\
\hline $\begin{array}{l}\text { Geographic and climatic } \\
\text { controls }\end{array}$ & Yes & Yes & Yes & Yes & Yes & Yes \\
\hline $\begin{array}{l}\text { Quadratic polynomial in } \\
\text { lattitude and longitude }\end{array}$ & Yes & Yes & Yes & Yes & Yes & Yes \\
\hline R-squared & 0.70 & 0.72 & 0.65 & 0.54 & 0.64 & 0.62 \\
\hline Observations & 217 & 356 & 356 & 356 & 356 & 356 \\
\hline
\end{tabular}

Notes: Variables descriptions are provided in Table A1. The geographic and climatic controls include altitude, ruggedness, temperature, precipitation, coast dummy, distance to the coast, capital city dummy, and distance to the capital city. Regressions include a constant term which is omitted for space considerations. Standard errors corrected for spatial dependence are in parentheses. 
Table 8. Adjacent municipalities analysis: Granada

\begin{tabular}{|c|c|c|c|c|c|c|}
\hline & \multicolumn{2}{|c|}{ Income } & \multicolumn{2}{|c|}{ Light density } & \multicolumn{2}{|c|}{ Vehicles per household } \\
\hline & $(1)$ & $(2)$ & $(3)$ & $(4)$ & $(5)$ & $(6)$ \\
\hline $\begin{array}{l}\text { Difference between old } \\
\text { lorcships and the rest }\end{array}$ & $\begin{array}{l}-0.028 \\
(0.021)\end{array}$ & $\begin{array}{l}-0.052 \\
(0.021)\end{array}$ & $\begin{array}{l}-0.512 \\
(0.166)\end{array}$ & $\begin{array}{l}-0.463 \\
(0.123)\end{array}$ & $\begin{array}{l}-0.039 \\
(0.02)\end{array}$ & $\begin{array}{l}-0.043 \\
(0.015)\end{array}$ \\
\hline $\begin{array}{l}\text { Differences in control } \\
\text { variables included }\end{array}$ & No & Yes & No & Yes & No & Yes \\
\hline R-squared & 0.00 & 0.47 & 0.00 & 0.38 & 0.00 & 0.29 \\
\hline \multirow[t]{3}{*}{ Observations } & 37 & 37 & 98 & 98 & 98 & 98 \\
\hline & \multicolumn{2}{|c|}{ Education } & \multicolumn{2}{|c|}{ Socioeconomic condition } & \multicolumn{2}{|c|}{$\begin{array}{l}\text { Long-term population } \\
\text { growth (1900-2001) }\end{array}$} \\
\hline & $(7)$ & $(8)$ & $(9)$ & $(10)$ & $(11)$ & $(12)$ \\
\hline $\begin{array}{l}\text { Difference between old } \\
\text { lorcships and the rest }\end{array}$ & $\begin{array}{l}-0.427 \\
(1.45)\end{array}$ & $\begin{array}{l}-0.655 \\
(1.041)\end{array}$ & $\begin{array}{l}-2.25 \\
(1.112)\end{array}$ & $\begin{array}{l}-1.582 \\
(1.043)\end{array}$ & $\begin{array}{l}-0.234 \\
(0.076)\end{array}$ & $\begin{array}{l}-0.177 \\
(0.056)\end{array}$ \\
\hline $\begin{array}{l}\text { Differences in control } \\
\text { variables included }\end{array}$ & No & Yes & No & Yes & No & Yes \\
\hline R-squared & 0.00 & 0.33 & 0.00 & 0.27 & 0.00 & 0.27 \\
\hline Observations & 98 & 98 & 98 & 98 & 98 & 98 \\
\hline
\end{tabular}

Notes: Variables' descriptions are provided in Table A1. The table reports the coefficient on the constant term from regressions in which the dependent variables measure the difference between each lordship municipality and a comparison group of neighboring royal towns. Standard errors corrected for spatial dependence are in parentheses. 
Table 9. Looking at the mechanisms

\begin{tabular}{|c|c|c|c|c|c|c|c|c|c|c|c|}
\hline & $\begin{array}{c}\text { Log } \\
\text { popula- } \\
\text { tion } 1787\end{array}$ & $\begin{array}{c}\text { Log } \\
\text { popula- } \\
\text { tion } \\
\text { density } \\
1787\end{array}$ & $\begin{array}{c}\text { Labor } \\
\text { force in } \\
\text { agricul- } \\
\text { ture } 1787\end{array}$ & $\begin{array}{c}\text { Labor } \\
\text { force in } \\
\text { low } \\
\text { qualifica- } \\
\text { tion jobs } \\
1787\end{array}$ & $\begin{array}{c}\text { Landless } \\
\text { workers } \\
1787\end{array}$ & $\begin{array}{c}\text { Land } \\
\text { concentra- } \\
\text { tion } 1980\end{array}$ & $\begin{array}{l}\text { State- } \\
\text { related } \\
\text { job } \\
\text { occupa- } \\
\text { tions }\end{array}$ & $\begin{array}{c}\text { Royal } \\
\text { employees } \\
\text { dummy }\end{array}$ & $\begin{array}{l}\text { Post office } \\
\text { in } 1878\end{array}$ & $\begin{array}{c}\text { Secular } \\
\text { clergly } \\
\text { over labor } \\
\text { force }\end{array}$ & $\begin{array}{c}\text { Secular and } \\
\text { regular } \\
\text { clergy over } \\
\text { population }\end{array}$ \\
\hline & $(1)$ & $(2)$ & $(3)$ & $(4)$ & $(5)$ & $(6)$ & $(7)$ & $(8)$ & $(9)$ & $(10)$ & $(11)$ \\
\hline Old lordship & $\begin{array}{l}-0.073 \\
(0.091)\end{array}$ & $\begin{array}{c}0.090 \\
(0.105)\end{array}$ & $\begin{array}{l}-0.898 \\
(2.899)\end{array}$ & $\begin{array}{c}0.692 \\
(1.961)\end{array}$ & $\begin{array}{l}-0.78 \\
(2.707)\end{array}$ & $\begin{array}{l}-1.643 \\
(1.306)\end{array}$ & $\begin{array}{c}-0.39 \\
(0.163)\end{array}$ & $\begin{array}{l}-0.116 \\
(0.071)\end{array}$ & $\begin{array}{l}-0.131 \\
(0.044)\end{array}$ & $\begin{array}{c}0.252 \\
(0.156)\end{array}$ & $\begin{array}{l}-0.077 \\
(0.054)\end{array}$ \\
\hline $\begin{array}{l}\text { Geographic and climatic } \\
\text { controls }\end{array}$ & Yes & Yes & Yes & Yes & Yes & Yes & Yes & Yes & Yes & Yes & Yes \\
\hline $\begin{array}{l}\text { Quadratic polynomial in } \\
\text { lattitude and longitude }\end{array}$ & Yes & Yes & Yes & Yes & Yes & Yes & Yes & Yes & Yes & Yes & Yes \\
\hline R-squared & 0.34 & 0.37 & 0.10 & 0.09 & 0.15 & 0.19 & 0.23 & 0.143 & 0.14 & 0.14 & 0.13 \\
\hline Observations & 349 & 349 & 348 & 348 & 345 & 350 & 348 & 348 & 356 & 348 & 349 \\
\hline
\end{tabular}

Notes: Variables' descriptions are provided in Table A1. Regressions include a constant term which is omitted for space considerations. Standard errors corrected for spatial dependence are in parentheses.

Table 10. Lordship and current state capacity

\begin{tabular}{|c|c|c|c|c|c|c|c|}
\hline & $\begin{array}{c}\text { Kindergartens } \\
\text { (places over } \\
\text { total } \\
\text { population) }\end{array}$ & $\begin{array}{c}\text { Children } \\
\text { under } 3 \\
\text { attending } \\
\text { school }(\%)\end{array}$ & $\begin{array}{c}\text { Street in bad } \\
\text { conditions } \\
(\%)\end{array}$ & $\begin{array}{c}\text { Roads in bad } \\
\text { conditions } \\
(\%)\end{array}$ & $\begin{array}{c}\text { Broadband } \\
\text { access } \\
\text { (ADSL lines } \\
\text { over } \\
\text { population) }\end{array}$ & $\begin{array}{l}\text { Broadband } \\
\text { dummy }\end{array}$ & $\begin{array}{r}\text { Regional } \\
\text { government } \\
\text { employees }\end{array}$ \\
\hline & $(1)$ & $(2)$ & $(3)$ & $(4)$ & $(5)$ & $(6)$ & $(7)$ \\
\hline Old lordship & $\begin{array}{r}-3.844 \\
(1.64)\end{array}$ & $\begin{array}{l}-9.031 \\
(4.292)\end{array}$ & $\begin{array}{c}3.362 \\
(1.239)\end{array}$ & $\begin{array}{l}2.988 \\
(1.27)\end{array}$ & $\begin{array}{r}-22.562 \\
(5.414)\end{array}$ & $\begin{array}{l}-0.275 \\
(0.072)\end{array}$ & $\begin{array}{l}-0.248 \\
(0.085)\end{array}$ \\
\hline $\begin{array}{l}\text { Geographic and climatic } \\
\text { controls }\end{array}$ & Yes & Yes & Yes & Yes & Yes & Yes & Yes \\
\hline $\begin{array}{l}\text { Quadratic polynomial in } \\
\text { lattitude and longitude }\end{array}$ & Yes & Yes & Yes & Yes & Yes & Yes & Yes \\
\hline R-squared & 0.07 & 0.07 & 0.11 & 0.10 & 0.38 & 0.23 & 0.14 \\
\hline Observations & 238 & 351 & 344 & 344 & 356 & 356 & 355 \\
\hline
\end{tabular}

Notes: Variables descriptions are provided in Table A1. Regressions include a constant term which is omitted for space considerations. Standard errors corrected for spatial dependence are in parentheses. 